\title{
Post-Wildfire Sedimentation in Saguaro National Park, Rincon Mountain District, and Effects on Lowland Leopard Frog Habitat
}

By John T.C. Parker

Prepared in cooperation with the NATIONAL PARK SERVICE

Scientific Investigations Report 2006-5235 


\section{U.S. Department of the Interior DIRK KEMPTHORNE, Secretary}

\section{U.S. Geological Survey \\ Mark D. Myers, Director}

\section{U.S. Geological Survey, Reston, Virginia: 2006}

For product and ordering information:

World Wide Web: http://www.usgs.gov/pubprod

Telephone: 1-888-ASK-USGS

For more information on the USGS--the Federal source for science about the Earth, its natural and living resources, natural hazards, and the environment:

World Wide Web: http://www.usgs.gov

Telephone: 1-888-ASK-USGS

Any use of trade, product, or firm names is for descriptive purposes only and does not imply endorsement by the U.S. Government.

Although this report is in the public domain, permission must be secured from the individual copyright owners to reproduce any copyrighted materials contained within this report.

Suggested citation:

Parker, John T.C., 2006 Post-wildfire sedimentation in Saguaro National Park, Rincon Mountain District, and effects on lowland leopard frog habitat: U.S. Geological Survey Scientific Investigations Report 2006-5235, 35 p. 


\section{Contents}

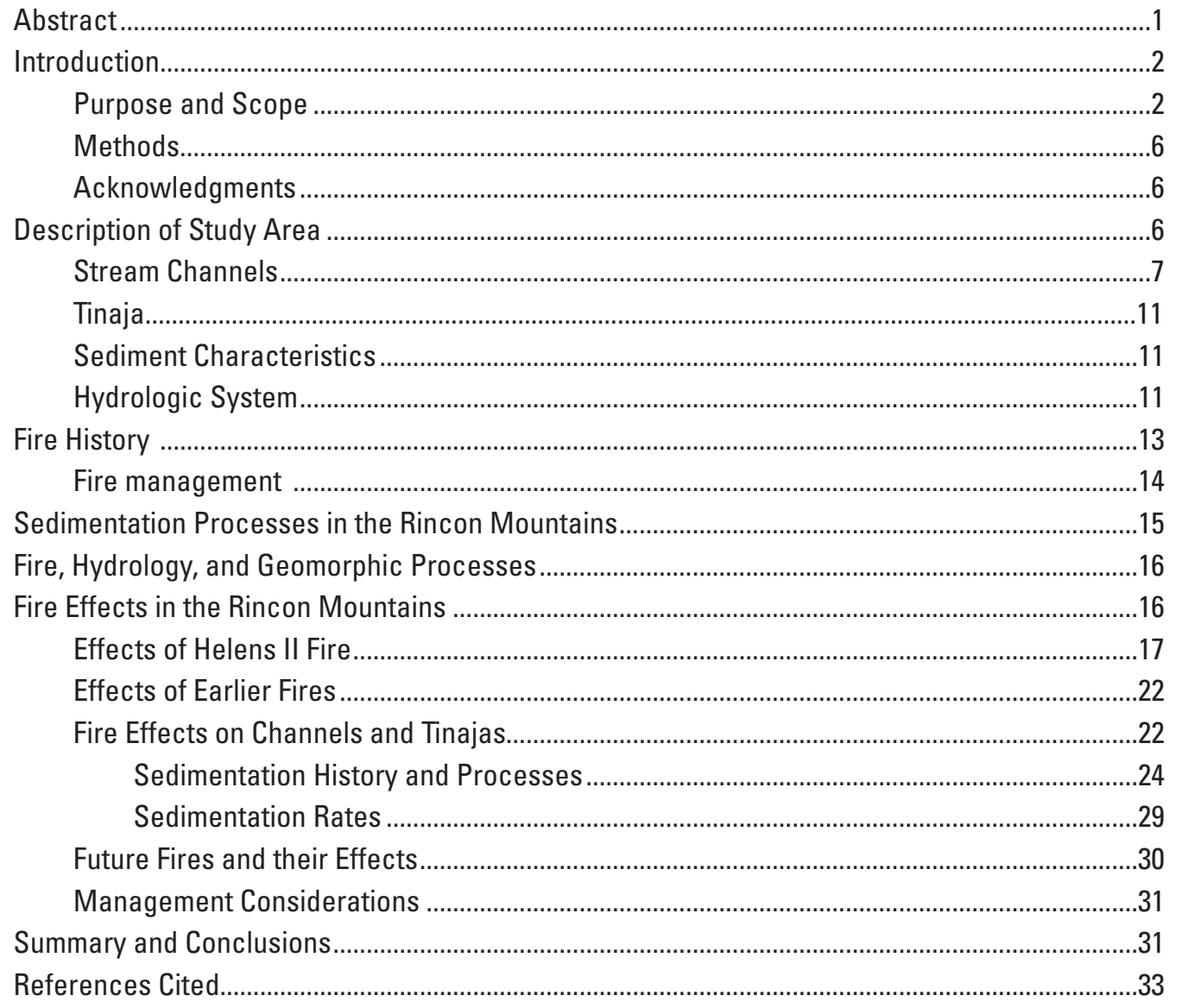




\section{Figures}

1. Map showingo study area and extent of major burns occurring 1989-2004, Saguaro National Park, Rincon Mountain District, Arizona

2. Photograph showing the lowland leopard frogs population in Saguaro National Park, Arizona .

3. Map showing location of leopard frog habitat in Saguaro National Park, Rincon Mountain District, Arizona

4. Sedimentation in tinajas in Saguaro National Park, Rincon Mountain District, Arizona.

A. A tinaja in Loma Verde Wash, 1997, before the 1999 Box Canyon Fire .5

B. The same tinaja several months after the 1999 Box Canyon Fire. .5

5. Map showing geology of Saguaro National Park, Rincon Mountain District, Arizona.....8

6. Profiles of stream that contain leopard frog habitat, Saguaro National Park, Rincon Mountain District, Arizona.

A. Streams draining Tanque Verde Creek watershed........................................................

B. Streams draining Rincon Creek watershed

7. Photograph showing typical polished bedrock channel, north fork of Rincon Creek, Saguaro National Park, Rincon Mountain District, Arizona..

8. Graph showing fire history in Rincon Mountains since 1943, Saguaro National Park, Rincon Mountain District, Arizona.

9. Photograph showing mixed-conifer forest above the North Slope Trail after the Helens II fire of 2003, Saguaro National Park, Rincon Mountain District, Arizona

10. Graph showing cumulative daily discharge for Rincon Creek station (09485000) and cumulative daily precipitation at Tucson, Arizona.
A. Winter 1991-92

B. Winter 1994-95.

11. Map showing Helens II burn area and Joaquin Canyon Saguaro National Park, Rincon Mountain District, Arizona.

12. Photographs showing post-wildfire erosion mechanisms, Saguaro National Park, Rincon Mountain District, Arizona.

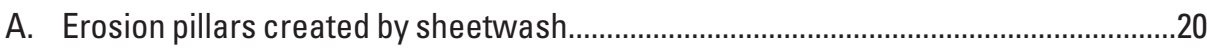

B. Weakly channelized flow on burned hillslope.........................................................20

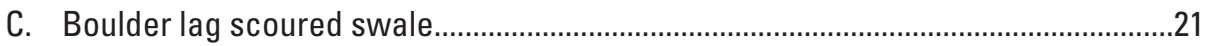

D. Coarse, poorly sorted, post-wildfire overbank deposit in Joaquin Canyon tributary.

13. Photographs showing stabilization of hill slopes in Helens II burn area, Saguaro National Park, Rincon Mountain District, Arizona.

A. Vegetation two years after fire

B. Formation of coarse gravel lag above finer soil matrix. 


\section{Figures-Continued}

14. Photograph showing Joaquin Canyon tinajas and channel in October 2005, Saguaro National Park, Rincon Mountain District, Arizona.
A. Pool JC1 .23
B. Pool JC5 .23
A. Downstream end of Joaquin Canyon near Tanque Verde Creek .23

15. Graph showing volume of tinajas and volume occupied by sediment in channels of Rincon Mountains, 2005-2006, Saguaro National Park, Rincon Mountain District, Arizona

16. Photographs showing tinaja in Wildhorse Canyon, Saguaro National Park, Rincon Mountain District, Arizona.
A. Before Chiva fire of 1989 . 25

B. After Chiva fire. .25

17. Photographs showing tinajas in Loma Verde Wash, Saguaro National Park, Rincon Mountain District, Arizona.
A. Tinaja LV4.
B. Tinaja LV9.

\section{Tables}

1. Physical characteristics of Rincon Mountain drainage basins with historic leopard frog habitat, Saguaro National Park, Rincon Mountain District, Arizona .

2. Particle size distribution of Rincon Mountain sediments, Saguaro National Park, Rincon Mountain District, Arizona . .12

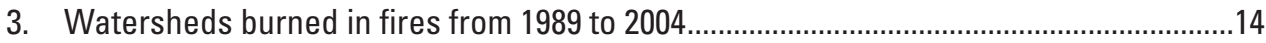

4. Highest intensity storms occurring after the Helens II fire recorded at Pima County Flood Control precipitation gage 4100 at Manning Camp..

5. Pool volume and volume of sediment for tinajas surveyed in 2005-06, Saguaro National Park, Rincon Mountain District, Arizona 


\section{Conversion Factors and Datums}

\begin{tabular}{lcl}
\hline \multicolumn{1}{c}{ Multiply } & \multicolumn{1}{c}{ By } & \multicolumn{1}{c}{ To obtain } \\
\hline centimeter $(\mathrm{cm})$ & Length & \\
millimeter $(\mathrm{mm})$ & 0.3937 & inch (in.) \\
meter $(\mathrm{m})$ & 0.03937 & inch (in.) \\
kilometer $(\mathrm{km})$ & 3.281 & foot (ft) \\
meter $(\mathrm{m})$ & 0.6214 & mile (mi) \\
\hline & 1.094 & yard (yd) \\
\hline hectare $(\mathrm{ha})$ & Area & \\
square kilometer $\left(\mathrm{km}^{2}\right)$ & 2.471 & acre \\
hectare $($ ha) & 247.1 & acre \\
square kilometer $\left(\mathrm{km}^{2}\right)$ & 0.003861 & square mile $\left(\mathrm{mi}^{2}\right)$ \\
\hline & 0.3861 & square mile $\left(\mathrm{mi}^{2}\right)$ \\
\hline cubic meter $\left(\mathrm{m}^{3}\right)$ & Volume & \\
\hline & 35.31 & cubic foot $\left(\mathrm{ft}^{3}\right)$ \\
\hline cubic meter per second $\left(\mathrm{m}^{3} / \mathrm{s}\right)$ & Flow rate & \\
\hline & 35.31 & cubic foot per second $\left(\mathrm{ft}^{3} / \mathrm{s}\right)$ \\
\hline kilogram $(\mathrm{kg})$ & Mass & pound avoirdupois $(\mathrm{lb})$ \\
\hline & 2.205 & pound per cubic foot $\left(\mathrm{lb} / \mathrm{ft}^{3}\right)$ \\
\hline kilogram per cubic meter $\left(\mathrm{kg} / \mathrm{m}^{3}\right)$ & Density
\end{tabular}

Temperature in degrees Celsius $\left({ }^{\circ} \mathrm{C}\right)$ may be converted to degrees Fahrenheit $\left({ }^{\circ} \mathrm{F}\right)$ as follows:

$$
{ }^{\circ} \mathrm{F}=\left(1.8 x^{\circ} \mathrm{C}\right)+32
$$

Vertical coordinate information is referenced to the North American Vertical Datum of 1929 (NGVD of 1929).

Horizontal coordinate information is referenced to the North American Datum of 1983 (NAD 83). 


\title{
Post-Wildfire Sedimentation in Saguaro National Park, Rincon Mountain District, Arizona, and Effects on Lowland Leopard Frog Habitat
}

\author{
By John T.C. Parker
}

\section{Abstract}

The Rincon Mountain District of Saguaro National Park occupies about 272 square kilometers of mountains, canyons, and alluvial fans in southeastern Arizona just east of Tucson. The park contains some of the last remaining habitat in the Tucson Basin of the lowland leopard frog that lives in the bedrock pools called tinajas in canyons at elevations between 850 and 1,800 meters. Those tinajas that contain water yearround are critical winter habitat for tadpoles, and the breeding success of the leopard frogs depends on these features. In recent years, many tinajas that previously had provided habitat for the leopard frogs have been buried beneath large volumes of coarse sandy gravel that resulted from severe, standreplacing wildfires in the watersheds above them.

The U. S. Geological Survey in cooperation with the National Park Service, conducted a study in 2004-06 to determine critical sediment-source areas, and the mechanisms of sediment delivery from hillslopes to stream channels to areas of leopard frog habitat and to estimate the increase in rates of sedimentation resulting from wildfires.

Spatial data of watershed characteristics, as well as historical data, including photographs, monitoring surveys, precipitation and stream discharge records, were used in conjunction with field observations conducted between spring 2004 and fall 2005. The Helens II fire in 2003, the fifth largest wildfire to burn in the Rincon Mountains since 1989, offered an opportunity to observe mechanisms of sediment erosion, transport, and deposition in the immediate post-fire environment.

Reduction of the forest canopy, understory vegetation, and organic litter on the ground surface in severe burn areas caused increased surface runoff in the Joaquin Canyon watershed that led to intensified erosion of hillslopes. An initial flush of fine material, mostly ash, was transported to lower channel reaches with the first significant precipitation event following the fire. Subsequently, the main erosional mechanisms were rainsplash and sheetwash that delivered high sediment loads to headwater tributaries. The increased runoff also led to scouring of the headwater tributaries and the downstream transport of a sediment slug by a series of episodic debris flows or hyperconcentrated flows.
The sediment slug, following intense summer precipitation, moved downstream several hundred meters at a time. Sediment was remobilized during subsequent periods of runoff. As of fall 2005, sediment had traveled $3.3 \mathrm{~km}$ downstream from the nearest burn area margin and had buried several tinajas in as much as a meter of sediment. Sediment continued to overwhelm the transport capacity of the channel even as the hillslopes in the burn area were showing evidence of recovery.

The sedimentation history and effects on leopard frog habitat in other channels in the Rincon Mountains was evaluated by analyzing observations made by Saguaro National Park staff during monitoring surveys of leopard frog populations. The best record of post-wildfire sediment deposition was that of Loma Verde Wash in which the filling of all tinajas in the two years after the 1999 Box Canyon fire was recorded. Monitoring of leopard frog populations in Wildhorse Canyon appeared to reflect the lingering effects of heavy sedimentation related to the 1989 Chiva fire.

Populations appear to be recovering in the upper tinajas, which were mainly free of sediment, but sightings of frogs were sparse in the lower tinajas that still contained high volumes of sediment. In Madrona Canyon, leopard frog sightings were sparse, possibly indicating that habitat had been detrimentally affected by the Rincon fire of 1994 .

Based on rates of filling of tinajas in Joaquin Canyon and Loma Verde Wash, minimum estimated rates of sediment yield from burn areas ranged from 425 to $1,960 \mathrm{~kg} \mathrm{ha}^{-1}$. The residence time of sediment in tinajas was found to be highly variable. Tinajas in Loma Verde Wash that were buried following the 1999 Box Canyon fire were still buried as of fall 2005. Some tinajas in Wildhorse Canyon that had been filled after the 1989 Chiva fire were also still filled with sediment 17 years after the fire. Persistent high volumes of sediment in the lower reaches of Loma Verde Wash and Wildhorse Canyon may reflect the morphology of those tinajas that are the result of structural features in the deformed rocks at the base of the Rincon Mountains that facilitate sediment deposition. Some tinajas below other major burn areas in Madrona Canyon and Rincon Creek were up to 40 percent filled with sediment, but it is not clear whether such sediment was an effect of the 1994 Rincon fire or was the result of normal, episodic erosion and deposition in the Rincon Mountains. 
The record of leopard frog monitoring in Chimenea Creek suggests that post-wildfire sedimentation has not greatly affected frog populations in the tinajas of that channel. The watershed above the tinajas is one of the few that has not been greatly affected by large wildfires in the past three decades although nearly half of the watershed has been subject to prescribed burns and smaller wildfires.

\section{Introduction}

High rates of sedimentation in stream channels following major wildfires have resulted in the loss of breeding habitat for the lowland leopard frog (Rana yavapaiensis) in the Rincon Mountain District of Saguaro National Park near Tucson, Arizona (fig. 1). The leopard frog was once abundant in the Tucson Basin, but the loss of perennial water sources that has accompanied human development in the area, as well as the introduction of non-native predators, has nearly eliminated local frog populations (fig. 2) (Arizona Game and Fish Department, 2006). A few isolated canyon pools, known in the Southwest as tinajas, near the base of the Rincon Mountains harbor some of the last remaining populations of leopard frogs in the Tucson Basin. Perennial tinajas contain water year-round that supplies over-winter habitat to leopard frog tadpoles and is essential to the frogs' continued existence in the Tucson Basin.

The tinajas that provide leopard frog habitat are located in stream channels at elevations between 850 and $1,800 \mathrm{~m}$ in the Rincon Mountains. Leopard frog individuals or populations have been observed by park staff in at least 265 tinajas and leopard frog tadpoles or eggs, which signify a possible breeding populations, have been seen in 110 of those (fig. 3). Following the Box Canyon fire in 1999, every tinaja in Loma Verde Wash (fig. 4), which at that time contained one of the largest breeding populations of leopard frogs in the park, was buried in sediment and remained so at least seven years after the fire. As of summer 2006, no leopard frogs were known to occupy any part of Loma Verde Wash.

The decline in the numbers of leopard frogs in the Tucson Basin has paralleled the species' decline throughout other areas of Arizona and throughout half of its range in the United States (Arizona Game and Fish Department, 2006). This decline has led to designation of the lowland leopard frog as a Priority Vulnerable Species in the Sonoran Desert Conservation Plan implemented by Pima County in Arizona and as a Species of Special Concern by the Arizona Game and Fish Department. Lowland leopard frogs were also selected as one of three indicators of ecosystem health for Saguaro National Park (Pima County, 2006).

The U.S. Geological Survey, in cooperation with the National Park Service, conducted a study of post-wildfire sedimentation in Saguaro National Park to determine critical sediment source areas, determine the mechanisms of sediment delivery from hillslopes to stream channels to areas of leopard frog habitat, and to estimate the increase in rates of sediment erosion, transport and deposition resulting from wildfires. Funding was provided through the NPS-USGS Water Quality Partnership Program. The study area was the $272 \mathrm{~km}^{2}$ Rincon Mountain District of the park located on the east edge of the city of Tucson, but some additional observations were made in downstream areas in Coronado National Forest.

\section{Purpose and Scope}

The purpose of this report is to describe pre-fire and postfire sedimentation processes in the Rincon Mountains and the adjacent desert lowlands in Saguaro National Park, particularly as they relate to their effects on leopard frog habitat. In addition, the report presents an analysis of watershed physical characteristics that control spatial variability in the magnitude, timing, and rate of sediment entrainment and transport within the study area and identifies those areas most susceptible to catastrophic sedimentation in the event of future major wildfires. The findings are intended to provide park managers with an understanding of such processes to assist in developing fire management and wildlife management strategies for protecting park resources.

The basic objectives of the study are to:

1. Determine mechanisms of sediment delivery from burned areas and the change in sediment yields caused by burning of the watersheds.

2. Determine source areas of excess sedimentation in burned areas and their physical characteristics, such as topography, geology, soil type and thickness, and effects of fire on soil properties.

3. Estimate the background rates of sedimentation in perennial bedrock pools within the study area and characterize the sediments in pools that presently provide adequate habitat for the leopard frog and other aquatic species as well as in pools that have been rendered unfit for habitat because of excessive sedimentation.

4. Estimate potential sediment yield from unburned areas in the event of future fires.

The scope of work included the collection, compilation and analysis of existing hydrologic, geomorphic, vegetation, fire history and aquatic habitat data, including field observations, Geographic Information Systems (GIS) coverages, repeat photography and channel surveys provided by park service staff and other sources. In addition, field observations were conducted between spring 2004 and fall 2005 to identify mechanisms of sediment transport on hillslopes in areas with varying fire histories and to track the movement of sediment in stream channels beneath recently burned watersheds. The relative susceptibility of stream channels to catastrophic sedimentation in the event of future fires is presented in this report. 


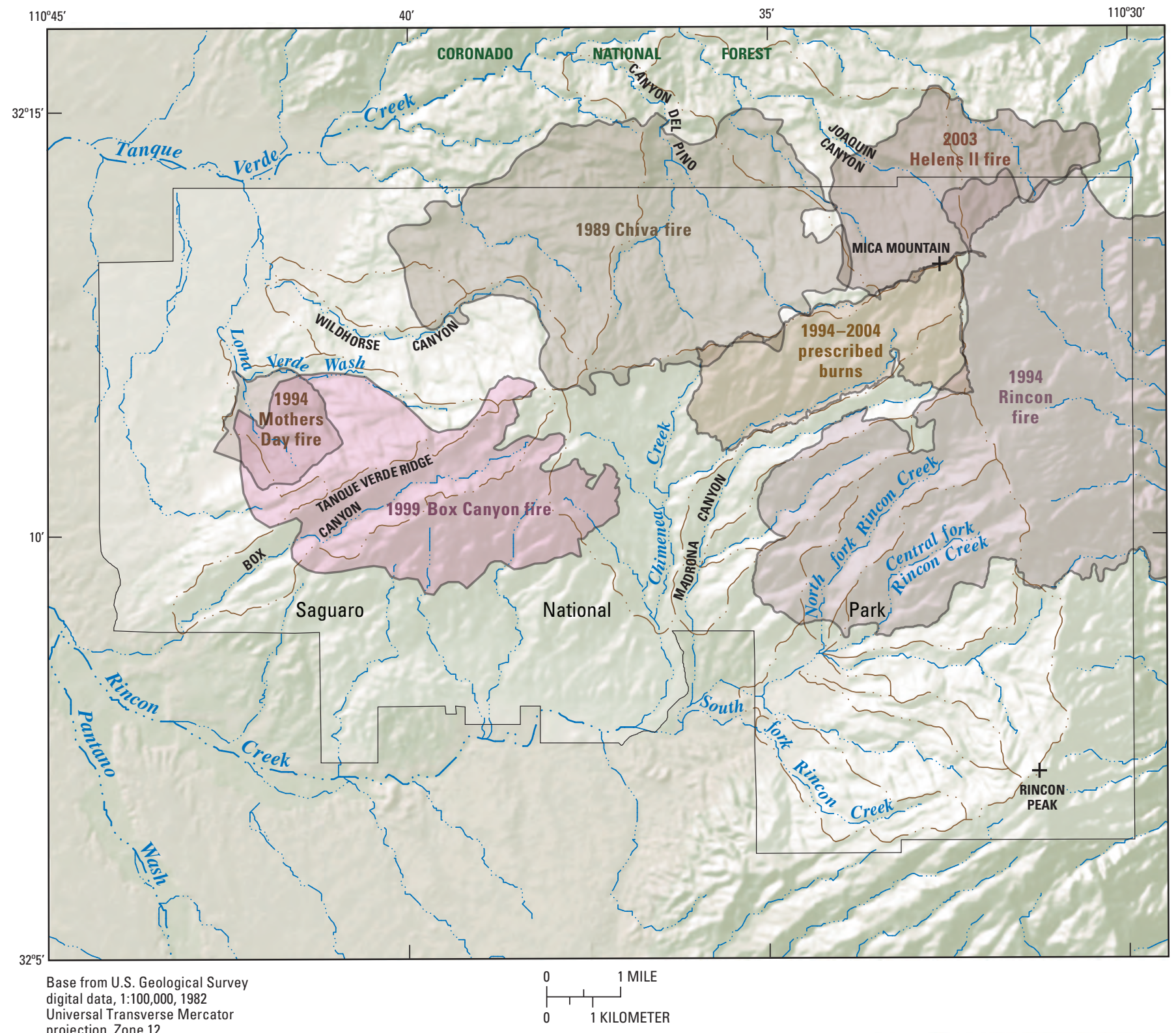

EXPLANATION

BOUNDARY OF NATIONAL PARK

BOUNDARY OF BASIN

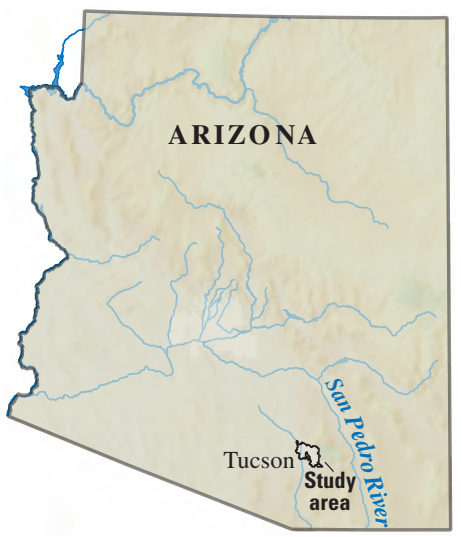

Figure 1. Location map of study area and extent of major burns occurring 1989-2004, Saguaro National Park, Rincon Mountain District, Arizona. 
Figure 2. (Right) Lowland leopard frogs in Saguaro National Park, Rincon Mountain District, Arizona. (Photograph by Erik Enderson, Tucson, Arizona.)

Figure 3. (Below) Location of leopard frog habitat in Saguaro National Park, Rincon Mountain District, Arizona.
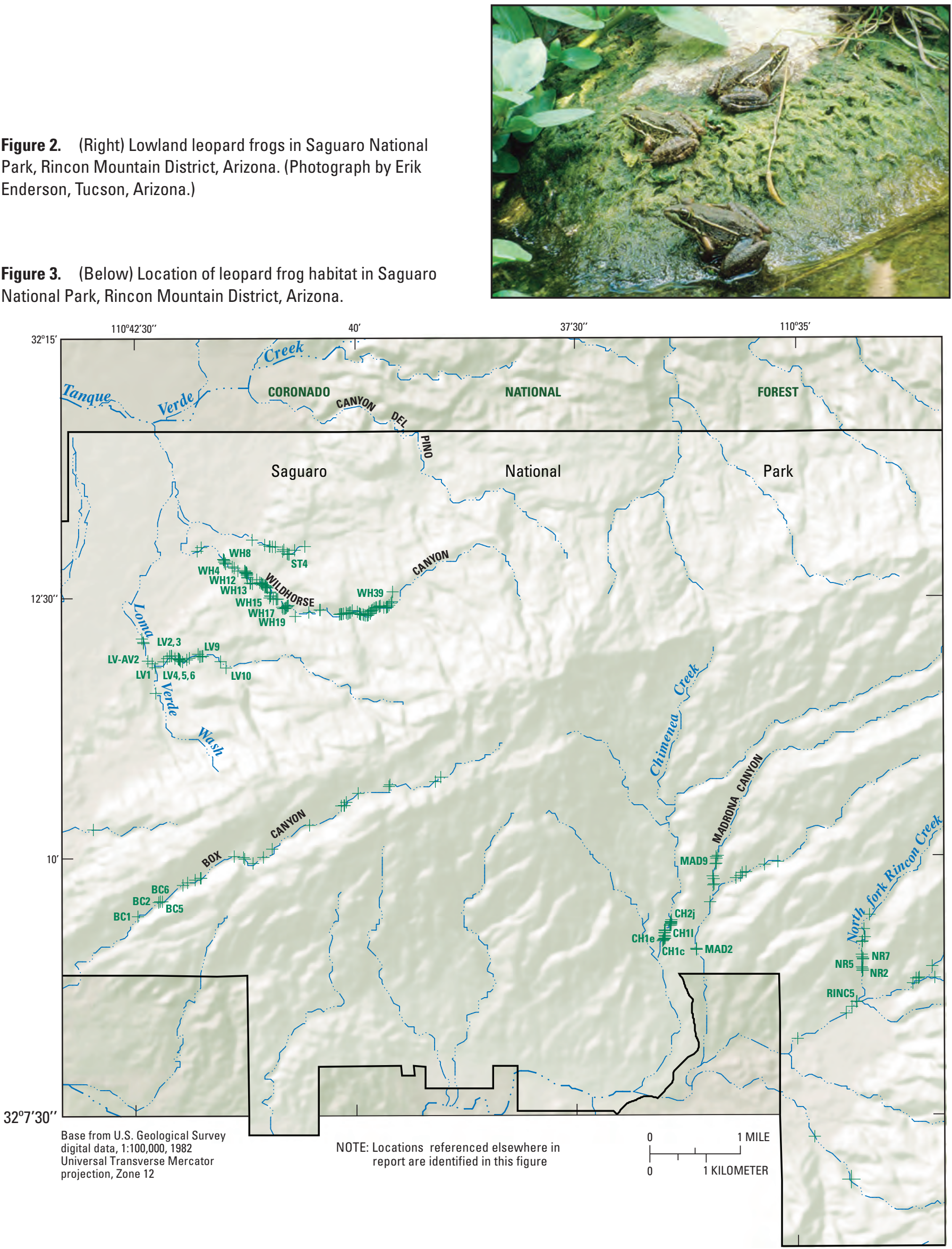
A. Before fire

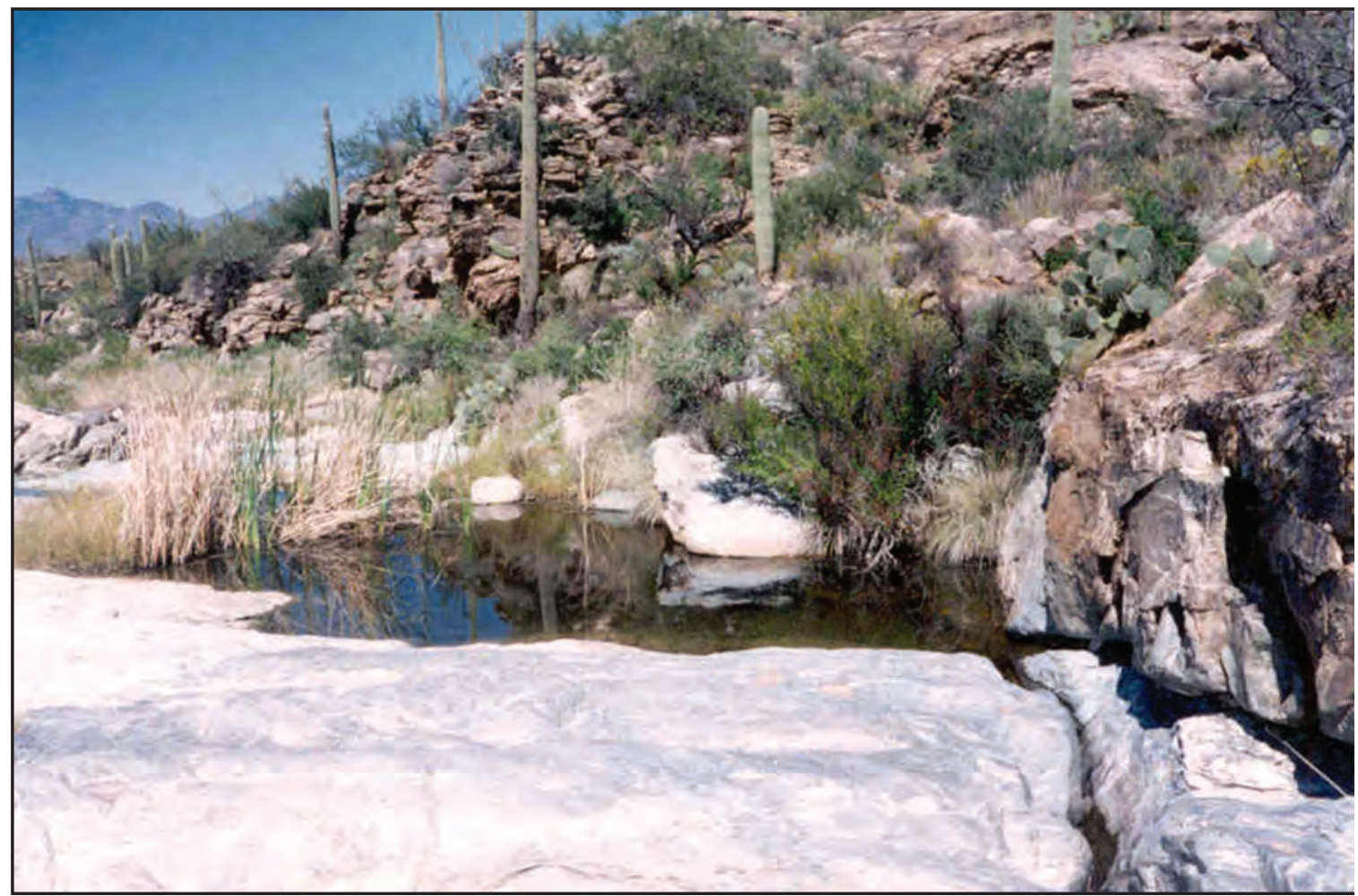

B. After fire

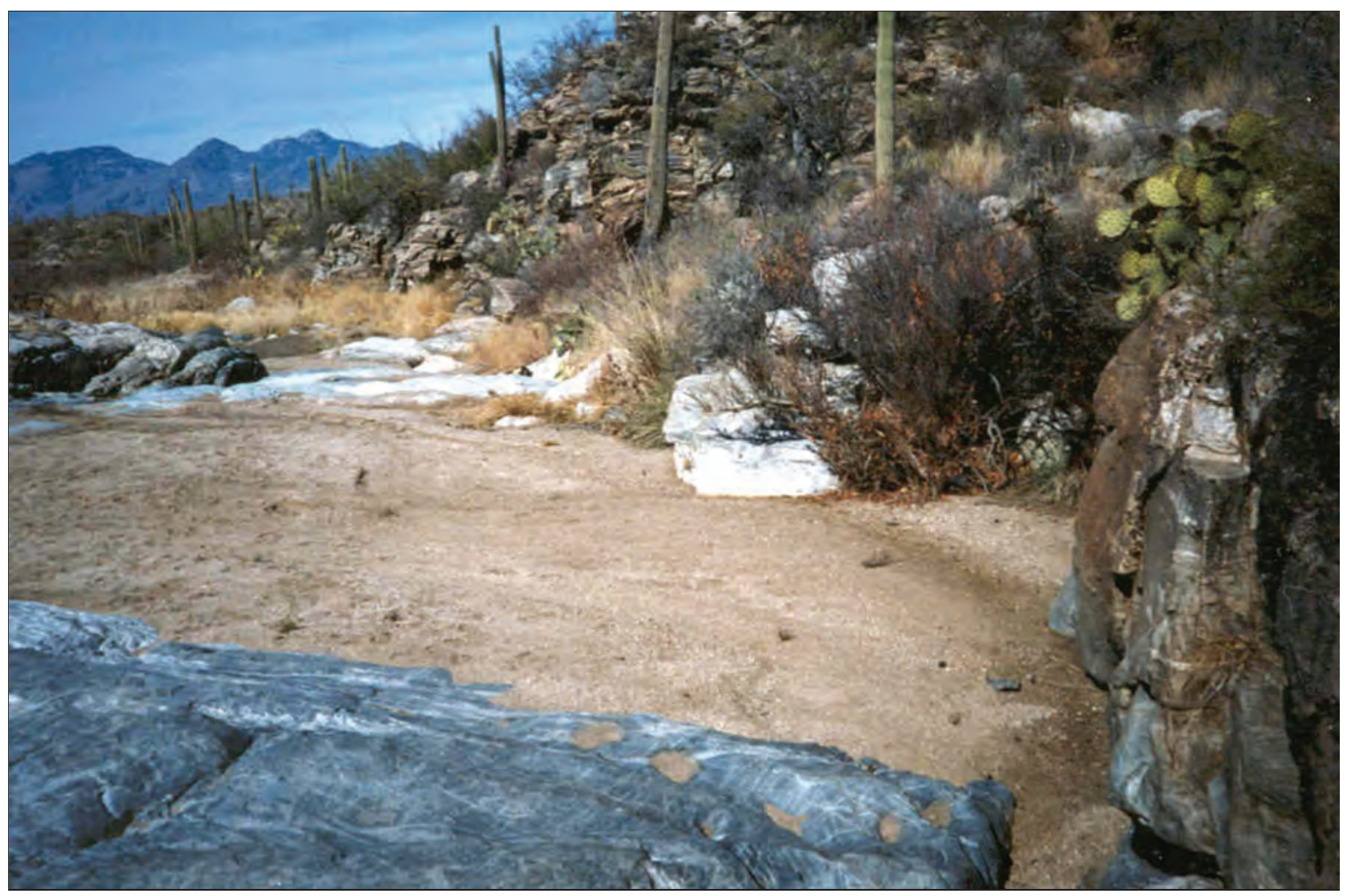

Figure 4. Sedimentation in tinajas in Saguaro National Park, Rincon Mountain District, Arizona. $A, A$ tinaja in Loma Verde Wash, 1997, before the 1999 Box Canyon Fire; and $B$, the same tinaja several months after the 1999 Box Canyon Fire. (Photographs by Don Swann, Saguaro National Park.) 


\section{Methods}

The study involved the analysis of spatial data to determine watershed characteristics and the relation of fire and sedimentation to topography, vegetation, geology, and soils; analysis of historical data to estimate the timing and magnitude of sedimentation events and their relation to fire occurrence, precipitation, and streamflow and field observations to determine the mechanisms of sediment transport and the relative magnitude of erosion, sediment transport, and deposition.

Spatial data was primarily in the form of GIS coverages of watershed characteristics compiled by park and USGS staff and during a previous inventory of park water resources (MacLeod and others, 2003). Aerial photographs were collected for the study but proved to be of inadequate resolution for assessing channel and hillslope conditions. Historical data included sequential photographs of tinajas, precipitation, streamflow records, and monitoring records of leopard frog habitat.

Field observations involved investigation of channel and hillslope conditions for evidence of the timing, magnitude and mechanisms of sediment erosion, transport and deposition, such evidence including the distribution of erosional features such as rills, erosion pillars, soil slips and channel scour (Selby, 1993; Cannon and others, 1998, 2001) and depositional features such as sand splays, dry ravel aprons, gravel deposits in channels and natural levees and massive sand deposits (Florsheim and others, 1991; Wohl and Pearthree, 1991).

Most field surveys were conducted within the Helens II burn zone and in the stream channels of Joaquin Canyon in Coronado National Forest lands north of the park boundary as well as in the channels of Loma Verde Wash (fig. 1). Reconnaissance surveys of watersheds in older burn areas including the Chiva, Box Canyon, and Rincon burn areas (fig. 1) were conducted to assess watershed recovery and a reconnaissance was also conducted of the watershed east of Rincon Creek, which has had no significant wildfire in more than 60 years. Channel conditions were also assessed in one-day surveys of Wildhorse Canyon, Box Canyon, the North Fork of Rincon Creek and upper Chimenea Creek. The locations of field observations were determined using a hand-held GPS device and important sites were photographed. GPS failures and poor photographic quality at many sites frustrated efforts to get good repeat photos during successive visits to sites in the Helens II burn area. Consequently, photographs used to illustrate examples of sedimentation mechanisms are not necessarily presented in chronological order unless so stated.

During these field surveys, 45 sediment samples were collected on hillslopes and in tinajas and stream channel beds for particle size analysis. Most samples were collected from the top $10 \mathrm{~cm}$ of the surface of the deposit. About $1 \mathrm{~kg}$ of sediment was collected at each site. Samples were dry sieved to determine particle size distributions, and descriptive statistics were generated using GRADISTAT, a program developed by Blott and Pye (2001). The maximum sieve opening used was $8 \mathrm{~mm}$. The largest particles were not measured but were about $50 \mathrm{~mm}$ along the long axis. Sediment particles of silt and clay-size $(<.0625 \mathrm{~mm})$ were weighed but were not analyzed for determination of the fine-grain size distribution. Fine-grained sediments that were textured by hand in the field and laboratory exhibited no cohesiveness, indicating that clay content was minimal.

Other fieldwork included a survey of 23 tinajas by park staff and volunteers in 2005-06 to measure the dimensions of each pool, determine the depth of sediment and the depth of water under full pool conditions, and to calculate the sediment and water volume for each pool.

\section{Acknowledgments}

A number of National Park personnel provided invaluable assistance in this project. Don Swann, biologist, helped with logistical arrangements for field work; helped secure data; and provided a wealth of biological observations in the course of this study. Matthew Daniels, NPS GIS specialist, also helped secure data and Mike Ward, NPS biological technician, assisted in fieldwork and was a cheerful and helpful companion during some particularly arduous field days. Other park staff provided logistical assistance and helped to make field accommodations at Manning Camp particularly comfortable and pleasant. Cheryl Simpson, a Pima Community College student, served as a volunteer on this project and did all of the sediment sieving. Robert Webb and Peter Griffiths of the USGS National Research Program arranged for use of soil sieving facilities at the University of Arizona Desert Research Station on Tumamoc Hill in Tucson.

\section{Description of Study Area}

The Rincon Mountain District of Saguaro National Park encompasses an area of rugged upland desert and mountainous terrain east of Tucson. Elevation ranges from about $760 \mathrm{~m}$ along the western edge of the park to about 2,600 $\mathrm{m}$ on Mica Mountain and Rincon Peak in the Rincon Mountains (fig. 1). Soils generally are thin except on some ridge tops and small upland basins; extensive exposures of bedrock occupy much of the higher elevation ridge crests. Mountains cover most of the park, but the most heavily visited areas are the bajadas, the rolling land surface of ridges and valleys formed by overlapping alluvial fans, along the base of the mountains at elevations between about 760 and $975 \mathrm{~m}$.

The climate is semiarid with summer and winter rainy seasons. Average annual precipitation near the base of the mountains is about $330 \mathrm{~mm}$ and is about $760 \mathrm{~mm}$ at the highest elevations (Bowers and McLaughlin, 1987). Storms that occur during the summer monsoon season typically are convective thunderstorms that are local in extent. Although 
such storms can produce intense precipitation, storms are brief, typically lasting less than a half hour, and rainfall distribution is often scattered so that flooding can occur in one drainage while a neighboring drainage is left dry. Winter precipitation occurs as a result of regional frontal storms in which rainfall typically is less intense but can last for several hours to several days. Snowfall is common above $2,100 \mathrm{~m}$ in the winter (Bowers and McLaughlin, 1987).

The bajadas of the lower elevations are blanketed with Sonoran Desert vegetation, which include extensive stands of saguaro cactus and other cacti as well as various yucca species and woody shrubs. With increasing elevation, the hillslopes are vegetated with grassland and scrubland, oak and juniper woodlands, juniper and piñon pine woodlands, Ponderosa pine forest, and mixed conifer forest (Bowers and McLaughlin, 1987).

The Rincon Mountains form a gneiss dome complex uplifted during the late Miocene Basin and Range extensional deformation 7-12 million years ago (Dickinson, 1991). The predominant rock types are Precambrian Continental Granodiorite and the Wrong Mountain Quartz Monzonite that have intruded into the older Pinal Schist (fig. 5, Poole, 2002). The granodiorite typically is metamorphosed and is very coarse grained and moderately to strongly foliated. Biotite and chlorite are pervasive (Drewes, 1977). The quartz monzonite intrudes the continental granodiorite and near the base of the Rincon Mountains the two units commonly are intercalated in thinly layered migmatic gneiss. The Wrong Mountain Quartz Monzonite typically is moderately coarse to fine-grained with abundant biotite and muscovite. Foliation is common but is weaker than in the Continental Granodiorite and Pinal Schist. Potassium-argon ages on biotite and muscovite in the Wrong Mountain Quartz Monzonite indicate recrystallization 24-25 m.y. ago in the late Oligocene (Drewes, 1974; 1977). Deformation of the rocks ranges from kilometer-scale fracturing to outcrop-scale foliation and folding. A number of metadiorite dikes, sills, and irregular rock masses intrude into the main bodies of granodiorite and quartz monzonite trending southwest-northeast across the central part of the study area (fig. 5).

The rocks typically weather to coarse, gravelly sand that covers most hillslopes although steep slopes of exposed bedrock are common. The Wrong Mountain Quartz Monzonite becomes increasingly massive near the crest of the Rincon Mountains and forms the peaks of Mica Mountain, Rincon Peak, as well as the prominent knobs of Helens Dome and Spud Rock (fig. 5) and shear cliffs near the ridges of the upper canyons and the north slope of the mountains. There are a few erosional remnants of sedimentary rocks of Cambrian to Cretaceous age near the northern and southwestern base of the mountains (fig. 5). Major Tertiary to Quaternary sediment rocks include terrace gravels in the northwest corner of the park and pockets of landslide rubble (Drewes, 1974; 1977), the largest of which are located in the lower reach of Chimenea Creek and on the east slope of the Rincon Mountains (fig. 5).

\section{Stream Channels}

About $460 \mathrm{~km}$ of stream channels within the park boundaries form a dense drainage network that dissects the hillslopes of the Rincon Mountains. The channels mainly drain into Rincon Creek and then into Pantano Wash on the west side of the park and into Tanque Verde Creek on the north side. Several small streams drain the steep eastern slopes into the San Pedro River basin (fig. 1). Although each channel shows great variation along its course, the streams and their drainage basins tend to be more similar than different (fig. 6, table 1). Headwaters of all streams other than Loma Verde Wash and Steel Tank extend to elevations above 2,000 m; most drainage basins have areas between 10 and $20 \mathrm{~km}^{2}$; drainage basins typically are steep with relief ratios between 0.140 and .190 and average hillslope angles between 28 and 36 percent. Channel densities are highest in the streams that drain into the Tanque Verde Creek watershed, with the exception of Joaquin Canyon, which has the second lowest channel density of the streams with known leopard frog populations and the south fork of Rincon Creek, which has the second highest channel density. Ordinarily, high channel density is associated with a system that has numerous branching tributaries, but in the case of the south fork of Rincon Creek the narrow linear shape of the watershed accounts for the high density value. Channel gradients average about 10 to 15 percent except for the central fork of Rincon Creek, which has a mean gradient of 17.6 percent and the east fork of Madrona Canyon, which has a mean gradient of 20 percent along the reaches measured (fig. 6).

Stream channels within the study area generally are bedrock controlled, and the variability of channel geometry depends on the geologic structure and lithology of the terrain over which the stream flows. Purely alluvial channels in which the channel banks and bed are mobile and channel morphology primarily controlled by stream discharge are confined to the lowest reaches on the bajadas of the north side of the mountains and in Rincon Valley on the south (fig. 1). Short alluvial reaches also occur in some upper tributaries where the channel passes through pockets of alluvium that have been deposited in small basins within the mountains. Headwater channels draining forested hillslopes can have alluvial banks and channel bottoms, but the bed and bank material typically is a thin mantle over what are essentially bedrock channels.

Many reaches, especially in the lower elevations, are a combination of bedrock and alluvial channels with outcrops of bedrock constricting or damming the channel between alluvial reaches several tens of meters long. Generally, the alluvial reaches are characterized by sand- and gravel-bed channels with discontinuous alluvial banks. Abundant protrusions of bedrock on the channel bottom in such reaches indicate the thinness of the alluvial layer. 


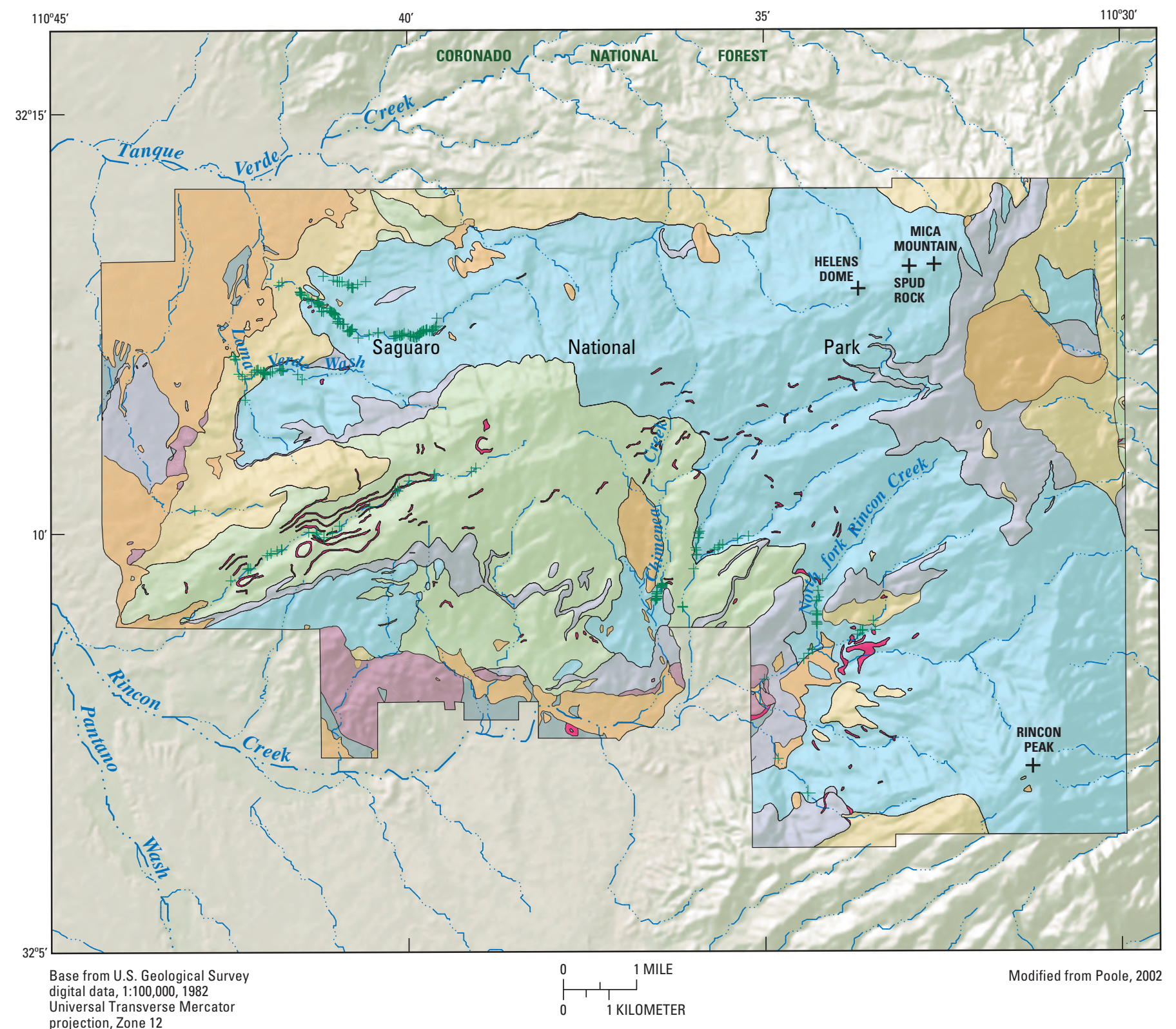

EXPLANATION

$\begin{aligned} & \text { OUATERNARY AND TERTIARY SEDIMENTARY } \\
& \text { ROCKS }\end{aligned}$
MESOZOIC AND PALEOZOIC SEDIMENTARY
ROCKS
CONTINENTAL GRANODIORITE
\begin{tabular}{|l}
$\square$ \\
$\square R O N G$ MT. OUARTZ MONZONITE AND \\
CONTINENTAL GRANODIORITE
\end{tabular}

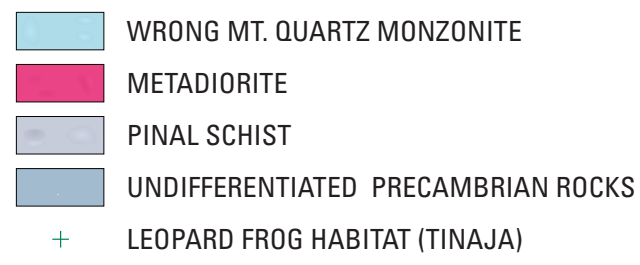

Figure 5. Geologic map of Saguaro National Park, Rincon Mountain District, Arizona. 
A. Tanque Verde Creek watershed

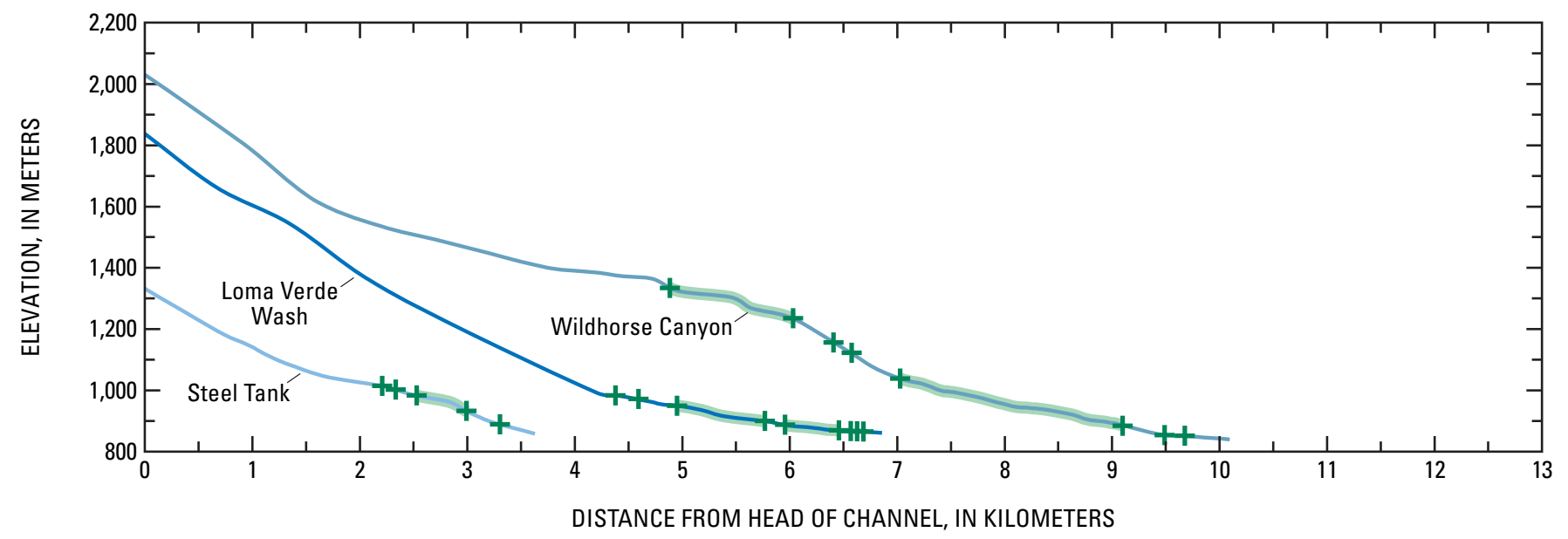

$B$. Rincon Creek watershed

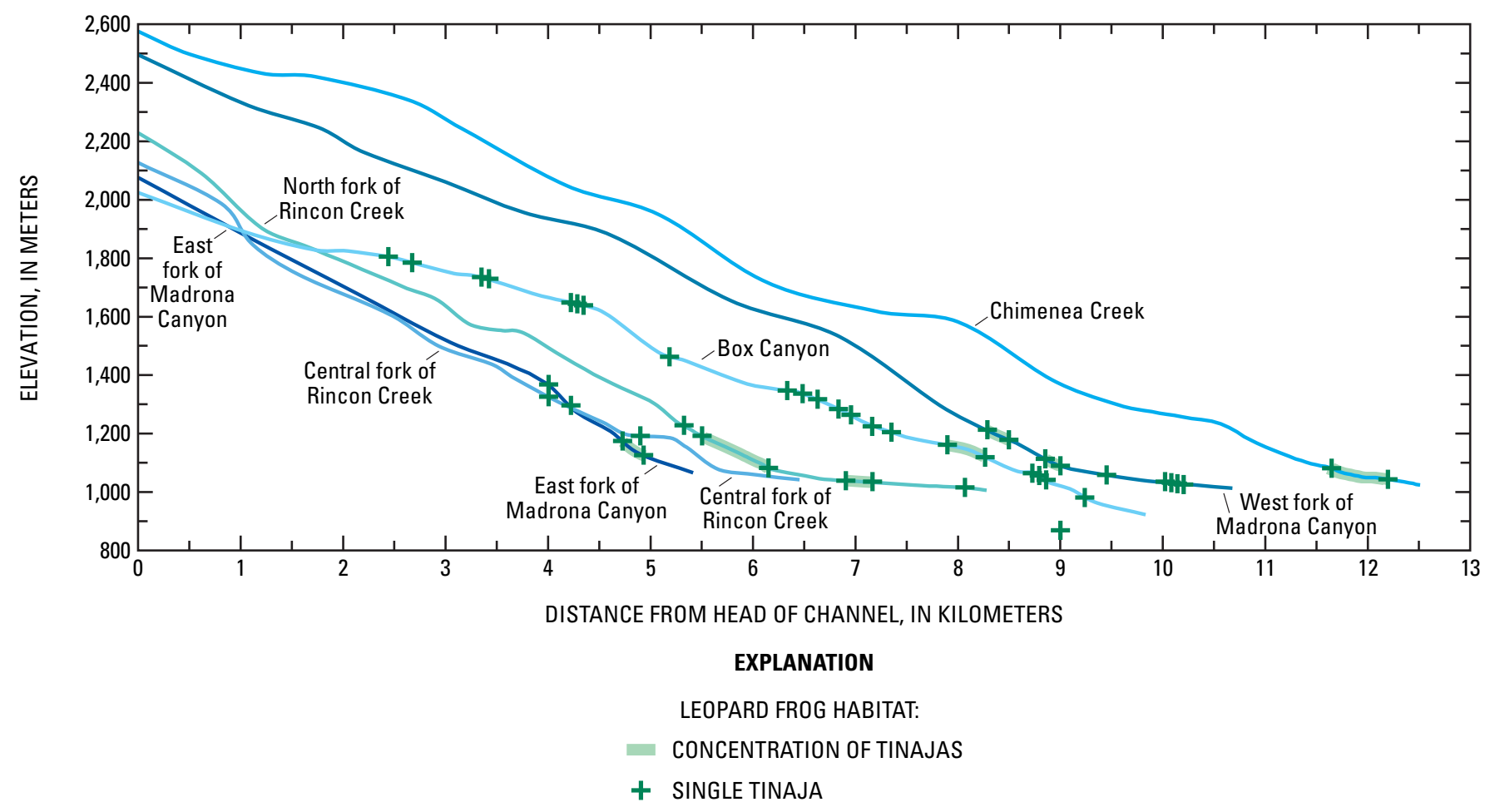

Figure 6. Profiles of stream that contain leopard frog habitat, Saguaro National Park, Rincon Mountain District, Arizona. $A$, Streams draining Tanque Verde Creek watershed; $B$, Streams draining Rincon Creek watershed. 
Table 1. Physical characteristics of Rincon Mountain drainage basins with historic leopard frog habitat, Saguaro National Park, Rincon Mountain District, Arizona

[Drainage density is the length of all streams in the watershed divided by the area. Relief ratio is the total elevation change in the watershed divided by distance parallel to the main stream valley between the highest and lowest points.]

\begin{tabular}{|c|c|c|c|c|c|c|c|c|}
\hline Drainage & $\begin{array}{c}\text { Area } \\
\text { (square } \\
\text { kilometers) }\end{array}$ & $\begin{array}{c}\text { Stream- } \\
\text { length } \\
\text { (kilometers) }\end{array}$ & $\begin{array}{c}\text { Drainage } \\
\text { density }\end{array}$ & $\begin{array}{c}\text { Maximum } \\
\text { elevation } \\
\text { (meters) }\end{array}$ & $\begin{array}{l}\text { Relief } \\
\text { ratio }\end{array}$ & $\begin{array}{c}\text { Mean } \\
\text { percent } \\
\text { hillslope }\end{array}$ & $\begin{array}{c}\text { Percent } \\
\text { hillslope } \\
\text { greater than } \\
45 \text { percent }\end{array}$ & $\begin{array}{c}\text { Number } \\
\text { of tinajas } \\
\text { where frogs } \\
\text { have been } \\
\text { observed }\end{array}$ \\
\hline Joaquin Canyon & 19.6 & 25.6 & 1.30 & 2,609 & 0.190 & 30.2 & 14 & $5^{1}$ \\
\hline Steel Tank & 3.59 & 9.46 & 2.64 & 1,425 & .131 & 21.6 & 9.4 & 13 \\
\hline Wildhorse & 10.4 & 21.4 & 2.06 & 2,135 & .158 & 30.4 & 14 & 113 \\
\hline Loma Verde Wash & 10.7 & 21.2 & 1.99 & 1,996 & .165 & 33.3 & 23 & 38 \\
\hline Box Canyon & 10.7 & 17.8 & 1.67 & 2,112 & .121 & 31.3 & 22 & 25 \\
\hline Chimenea & 24.9 & 45.2 & 1.81 & 2,640 & .145 & 28.5 & 11 & 24 \\
\hline Madrona & 14.3 & 21.5 & 1.51 & 2,550 & .146 & 34.4 & 22 & 20 \\
\hline Rincon north fork & 7.41 & 9.13 & 1.23 & 2,227 & .194 & 34.8 & 27 & 13 \\
\hline Rincon upper central fork & 11.1 & 19.9 & 1.80 & 2,340 & .151 & 34.2 & 22 & 6 \\
\hline Rincon lower central fork & 48.1 & 50.0 & 1.04 & 2,575 & .188 & 35.4 & 13 & 6 \\
\hline Rincon south fork & 5.0 & 10.2 & 2.03 & 2,255 & .221 & 33.3 & 25 & 2 \\
\hline
\end{tabular}

${ }^{1}$ Estimated value. Joaquin Canyon tinajas are outside of the park boundaries and have been monitored only since Helens II fire of 2003. Monitoring of all other tinajas began in 1996.

Channel reaches characterized by smooth, polished banks and bottom contain little or no alluvium. The smooth bedrock surface in such reaches commonly is several times wider than the main channel, which can appear as a groove worn into that surface or as a narrow slot where the channel has followed the course of a fracture within the bedrock (fig. 7). In a few reaches, where the channel is contained within canyon walls of fractured rock, the channel is clogged with boulders that can be as much as $4 \mathrm{~m}$ in diameter, and most flows follow a circuitous path through the interstices within the boulder pile.

Boulders and bedrock sills that block the channels create numerous falls of about 1 to $5 \mathrm{~m}$ high that give many bedrock reaches a staircase profile in longitudinal view. In other reaches, long stretches of bedrock chutes create a ramp profile.

In many cases, the channels are incised within an inner bedrock canyon that can range from a few meters to $20 \mathrm{~m}$ deep, which are inset within the deeper canyon walls bounded by the mountain slopes.

Figure 7. (Right) Typical polished bedrock channel, north fork of Rincon Creek, Saguaro National Park, Rincon Mountain District, Arizona.

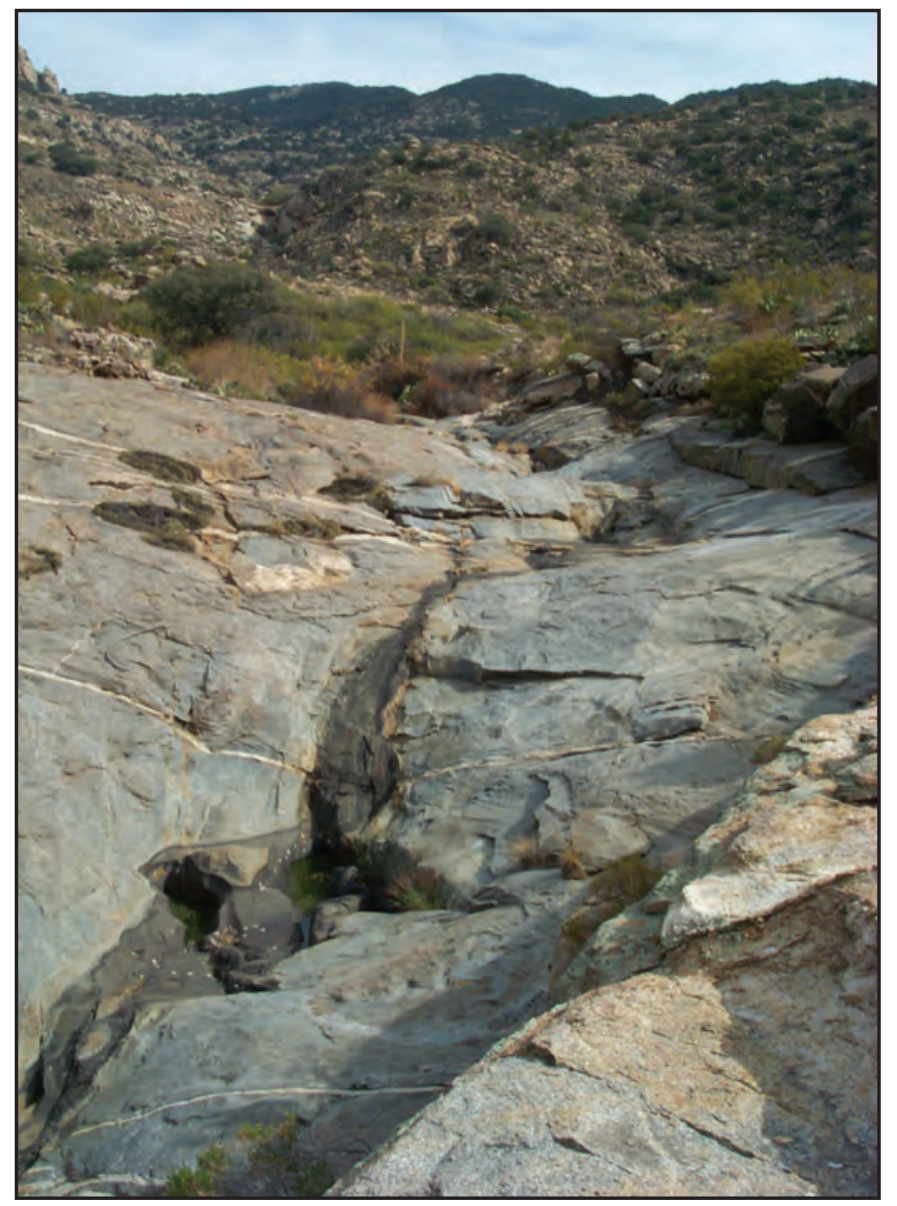




\section{Tinajas}

Tinajas exhibit a variety of morphologies dependent on the manner in which they are formed. Tinajas can result from ponding of water behind obstructions in the channel, including bedrock outcrops, sills and boulders. The basin upstream of the obstruction can be formed where boulders create an interstitial depression; where a section of rock has been plucked from the bedrock channel bottom along joint planes, or where a trough has been eroded into the channel bottom by abrasion. Such tinajas typically are roughly round or oval in shape and range from 1 to $3 \mathrm{~m}$ in diameter or length, but can be up to $10 \mathrm{~m}$ in length and 0.5 to $3 \mathrm{~m}$ deep. Plucking of rock fragments and blocks from jointed and fractured bedrock channels (Whipple and others, 2000) can also create tinajas confined within bedrock walls on all sides. These typically are rectangular, linear pools up to $10 \mathrm{~m}$ long and 0.5 to $2 \mathrm{~m}$ wide with vertical sides and angular corners that can become rounded from abrasion by sand and gravel in suspended sediment (Wohl, 1998; Whipple and others, 2000). Circular potholes, 1 to $3 \mathrm{~m}$, in diameter are a common feature within smooth, fluted bedrock reaches where rock is massive and unjointed. These tinajas are believed to be the product of physical erosion, such as abrasion from sediment in transport, and chemical erosion (Wohl, 1998), and they often occur in a chain of pools along the channel thalweg sometimes separated by a bedrock lip less than a meter wide. Abrasion also produces linear tinajas by eroding out a crevice along the base of fluted bedrock walls. A tinaja may be the product of one or all of these processes.

Most tinajas unaffected by recent post-wildfire sedimentation have little sediment on the pool bottom. A veneer of sand and gravel over a base of cobbles occurs in some tinajas and others have only a light layer of silt and organic ooze; however, sometimes one tinaja in a chain of pools will be nearly filled with sand and the others will have little or no such sediment. Some pools in low-gradient reaches, especially near the downstream end of the channels, have alluvial banks and a thicker layer of sediment on the bottom than is typical of most tinajas.

MacLeod and others (2003) identified at least 54 and 16 tinajas in the upper reaches of Chimenea Creek and the west branch of Madrona Canyon respectively at elevations between about 1,300 and 2,400 m elevation for which no leopard frog observations have been reported.

\section{Sediment Characteristics}

Gravel that ranges in size from large cobbles to boulders as much as $3 \mathrm{~m}$ in diameter strongly influences the morphology of the mountain landscape in the study area. Sediment transport; however, most commonly involves granular to small cobble-size gravel ( $2 \mathrm{~mm}-128 \mathrm{~mm}$ diameter) and sand (.0625 $\mathrm{mm}-2 \mathrm{~mm}$ diameter). Channel deposits, which include mainly channel bottom and tinaja sites, typically are poorly sorted sandy gravels with silt/clay content of less than five percent (table 2). Sample BC2a, the only sample to contain significant fine sediment other than the two samples that were not sieved, was collected from a vegetated sand bar adjacent to a tinaja. Such depositional environments are sparsely distributed in the Rincon Mountain channels.

There was no significant difference in median particle size $\left(\mathrm{D}_{50}\right)$ among hillslope, channel bed and tinaja deposits. All samples were poorly or very poorly sorted, which means that a wide range of particle sizes were contained in the samples (Folk, 1980). Poorly sorted sediments are typical of sediments that have been transported short distances by mechanisms that fluctuate in velocity (Pettijohn and others, 1987). Tinaja and channel deposits sampled tended to be slightly better sorted than hillslope sediments (table 2). The most consistent difference between hillslope and channel sediments was the higher silt/clay content of hillslope sediments with all 15 samples containing more than 5 percent fine-grained material and 6 samples containing more than 10 percent.

\section{Hydrologic System}

Water is scant in the Rincon Mountains. There are no perennial reaches of channel in the park, but a few springs and seeps provide limited surface water year round (MacLeod and others, 2003). Streamflow occurs mainly in response to runoff from intense summer or early fall thunderstorms and in response to snowmelt in winter and spring. The most reliable sources of surface water probably are deep tinajas that are well sheltered from sunlight to minimize evaporation and that receive some discharge from springs or seeps draining water stored in fractured rock that encloses the pools. MacLeod and others (2003) identified 70 tinajas in the Rincon Creek watershed and 5 in the Tanque Verde Creek watershed as perennial. Over the course of this study; however, southeast Arizona was experiencing severe drought. As of February 2006, 12-month precipitation totals in southern Arizona were less than 5 percent of the long-term average and 48-month precipitation totals were less than 15 percent of the longterm average (Arizona State University, 2006). In Saguaro National Park, park staff were seeing tinajas dry up for the first time since monitoring began in 1996 (Don Swann, Saguaro National Park biologist, personal commun., 2006). Given the relatively high precipitation levels of the previous three decades (Webb and Betancourt, 1992), the park in recent years has been undergoing its driest period since at least the 1950s. 
Table 2. Particle size distribution of Rincon Mountain sediments, Saguaro National Park, Rincon Mountain District, Arizona

[All percentages are by weight. D50 is median grain size. Location code: BC, Box Canyon; CP, Canyon del Pino; JC, Joaquin Canyon; LVW, Loma Verde Wash; SR, Spud Rock; NST, North Slope Trail; RC, Rincon Creek. Sorting code: PS, poorly sorted; MS, moderately sorted; VPS, very poorly sorted (Folk and Ward,1954; Folk, 1980). Textural class code: G, gravel; SG, sandy gravel; MSG, muddy sandy gravel; GS, gravelly sand; GMS, gravelly muddy sand (Folk and Ward, 1954; Folk,1980)]

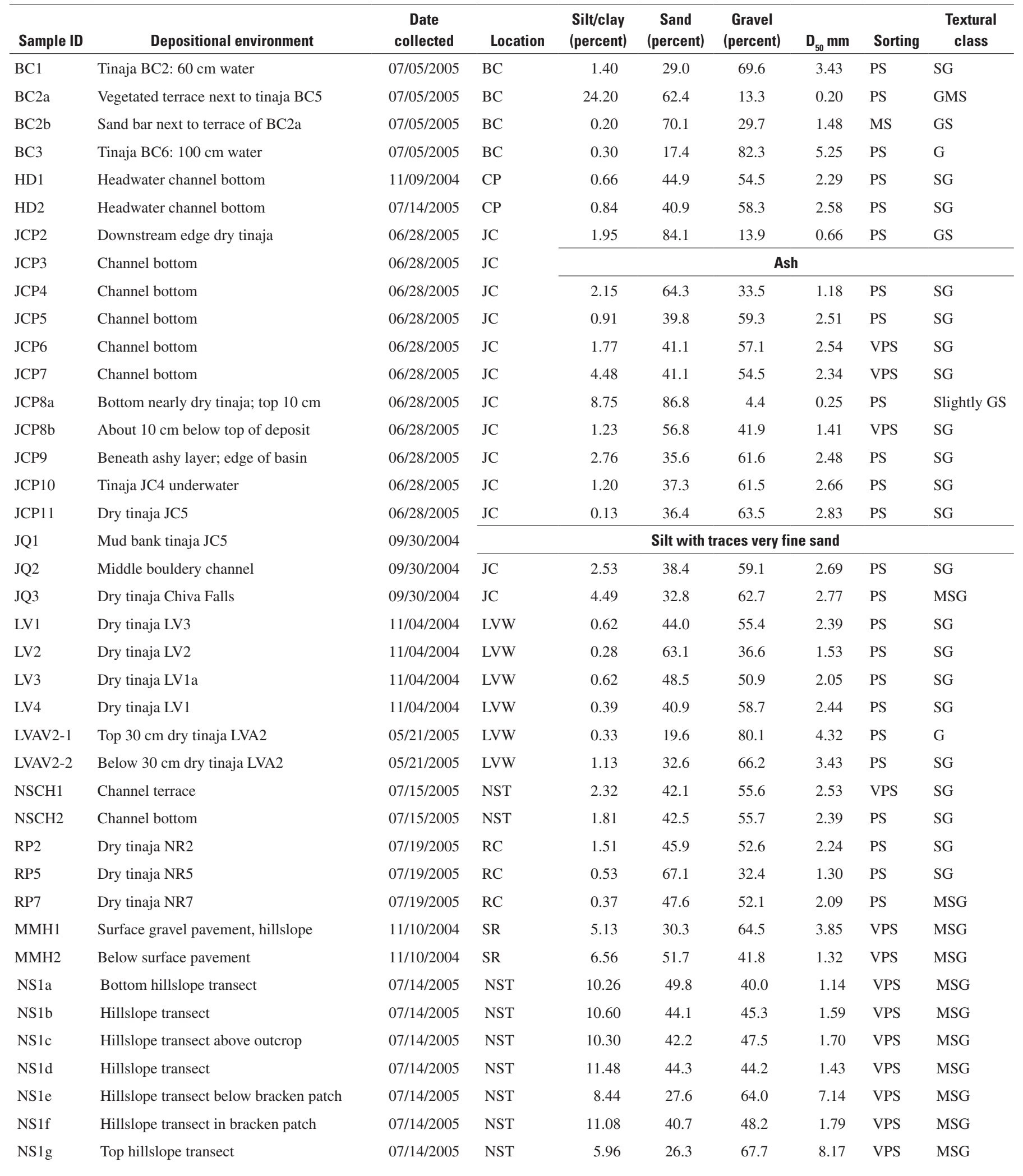


Table 2. Particle size distribution of Rincon Mountain sediments, Saguaro National Park, Rincon Mountain District, ArizonaContinued

\begin{tabular}{|c|c|c|c|c|c|c|c|c|c|}
\hline Sample ID & Depositional environment & $\begin{array}{c}\text { Date } \\
\text { collected }\end{array}$ & Location & $\begin{array}{c}\text { Silt/clay } \\
\text { (percent) }\end{array}$ & $\begin{array}{c}\text { Sand } \\
\text { (percent) }\end{array}$ & $\begin{array}{c}\text { Gravel } \\
\text { (percent) }\end{array}$ & $\mathrm{D}_{50} \mathrm{~mm}$ & Sorting & $\begin{array}{c}\text { Textural } \\
\text { class }\end{array}$ \\
\hline NS2 & Bottom and sides of rill & $07 / 15 / 2005$ & NST & 10.75 & 39.4 & 49.8 & 1.98 & VPS & MSG \\
\hline NS3b & Interill mid-slope & $07 / 15 / 2005$ & NST & 5.92 & 26.7 & 67.3 & 8.01 & VPS & MSG \\
\hline $\mathrm{NS} 3 \mathrm{c}$ & Top of rill & $07 / 15 / 2005$ & NST & 8.12 & 40.7 & 51.2 & 2.10 & VPS & MSG \\
\hline $\mathrm{NS} 4 \mathrm{c}$ & Hillslope upper & $07 / 15 / 2005$ & NST & 8.28 & 47.4 & 44.3 & 1.40 & VPS & MSG \\
\hline
\end{tabular}

\section{Fire History}

Tree-ring studies of fire history in the Rincon Mountains show that fire was a frequent and widespread phenomenon from 1657 to 1893 (Baisan and Swetman, 1990). Surface fires, generally between 200 and 3,000 ha in extent, burned the understory of ponderosa and mixed-conifer forests at intervals of 1-13 years in the vicinity of Mica Mountain. Mean fire interval was 6.1 years. During the period of unmanaged fire regimen studied by Baisan and Swetman (1990), fires ignited by lightning in May and June could burn for several months before being extinguished by summer rains.

Large, stand-replacing crown fires were rare in the Mica Mountain area before the 20th century although $8.5 \mathrm{~km}$ to the south at Rincon Peak, Baisan and Swetman (1990) regarded the presence of isolated stands of mature pines surrounded by oak brush and chaparral as evidence of a history of crown fires on that mountain. In a study of fire records from 1937 to 1987 , Rincon Peak had 9 lightning-caused ignitions compared to 350 on Mica Mountain. Baisan and Swetman (1990) suggest that the reason for the different fire histories is that the treeless top of Rincon Peak draws most of the lightning strikes in the immediate area and the absence of fuel in the strike zone limits establishment of fires in the forest below the peak. Lightning strikes in the Mica Mountain area are more dispersed into the forested area around the mountain top where they are more likely to cause ignition of vegetation. The infrequency of lightning-caused ignitions on Rincon Peak could result in less frequent understory fires and allow fuel accumulations that set the stage for crown fires.

Fire frequency declined in the late 19th and into the 20th century in the Rincon Mountains and throughout the Southwest as a result of fire suppression practices and livestock grazing that removed the forest understory (Baisan and Swetman, 1990). Except for large fires of 2,444 ha and 2,338 ha in 1943 and 1954 respectively, park records show only 409 ha burned in the period 1943-88. Then, in the period 1989-2003, five wildfires burned a total of 17,400 ha, more than 3 times the total area of all other fires combined for the period 1943-2003 (fig. 8, table 3).
Of the recent fires, the Rincon fire of 1994 was the largest historical fire, burning about 5,360 ha in the park and in Coronado National Forest lands surrounding the park (figs. 1 and 8). Fire size is based on the perimeter of the fire area and may include sizeable swaths of vegetation that are untouched by fire as well as many individual trees and other plants that are lightly burned and ultimately survive.

Fires have burned through nearly 40 percent of the park's forests, grasslands and scrublands since 1989, involving about 50 percent of the forested areas and 35 percent of chaparral and desert scrublands and grasslands. The Chiva, Mothers Day, and Box Canyon fires accounted for most of the burned acreage in scrublands and grasslands and the Rincon and Helens II fires primarily burned upper elevation forests and woodlands. The north slope of Mica Mountain was particularly hard hit by the fire, which caused near-total destruction of many stands of Ponderosa pine and other conifers (fig. 9); however, other stands within the fire area were virtually untouched and many trees survived the fire despite charring of trunks and branches.

Several recent fires are notable for having burned large areas of grassland and scrublands, areas that were not commonly burned in earlier fires. Between 1937 and 1986, Ponderosa pine, mixed-conifer forest, and oak-juniper woodland accounted for about 89 percent of the vegetation type affected by fire with grass and brush accounting for the remainder (Bowers and McLaughlin, 1987). Nearly two-thirds of the vegetation affected by the fires of 1989-2003; however, was classified as scrubland or grassland. Although grassland is a fire-adapted ecosystem, Sonoran desert scrubland is not, and the invasion of Sonoran desert lands by exotic grass species, particularly red brome and bufflegrass may contribute to an increase in fire frequency in such areas (Esque and Schwalbe, 2006). The Mother's Day fire of 1994 was the result of a lightning-caused ignition that was fueled by exotic grasses (Esque and others, 2003; Esque and Schwalbe, 2006). The possible role of exotic grasses in the Box Canyon and Chiva fires that burned extensive lower elevation areas in the park has not been investigated. 


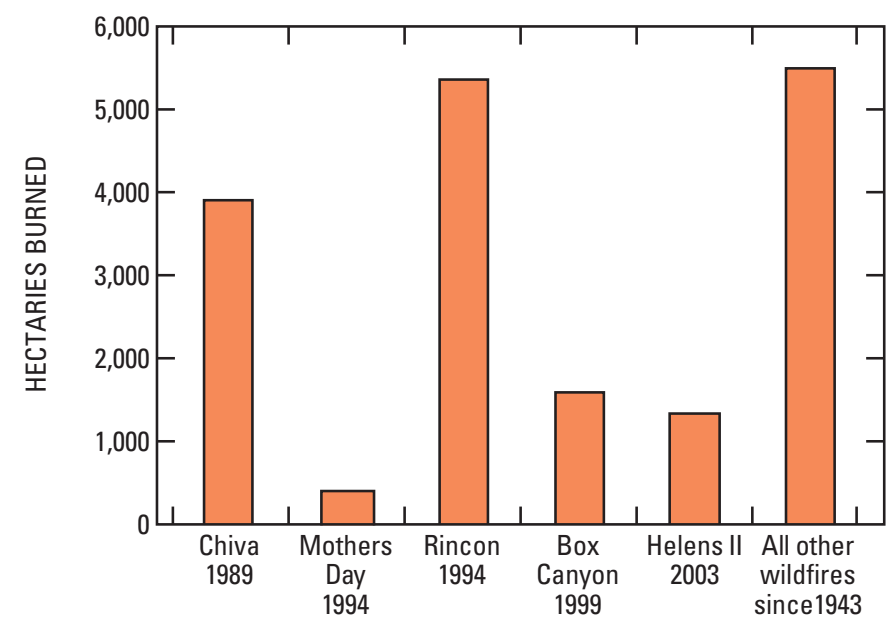

Figure 8. Fire history in Rincon Mountains since 1943, Saguaro National Park, Rincon Mountain District, Arizona.

Table 3. Watersheds burned in fires from 1989 to 2004. Only watersheds containing historic leopard frog populations shown (National Park Service, unpublished data, Saguaro National Park, Rincon Mountain District, Arizona, 2006)

\begin{tabular}{|c|c|c|c|c|}
\hline Watershed & $\begin{array}{l}\text { Year(s) } \\
\text { burned }\end{array}$ & Fire name & $\begin{array}{c}\text { Area } \\
\text { burned } \\
\text { (hectares) }\end{array}$ & $\begin{array}{l}\text { Watershed } \\
\text { burned } \\
\text { (percent) }\end{array}$ \\
\hline Joaquin Canyon & 1989 & Chiva & 248 & 13 \\
\hline Joaquin Canyon & 2003 & Helens II & 843 & 43 \\
\hline Steel Tank & 1989 & Chiva & 110 & 31 \\
\hline Wildhorse Canyon & 1989 & Chiva & 179 & 17 \\
\hline Wildhorse Canyon & 1999 & Box Canyon & 34 & 3.3 \\
\hline Loma Verde Wash & 1994 & Mothers Day & 394 & 37 \\
\hline Loma Verde Wash & 1999 & Box Canyon & 727 & 68 \\
\hline Box Canyon & 1999 & Box Canyon & 654 & 61 \\
\hline Chimenea Creek & 1994-2004 & Prescribed & 1,263 & 43 \\
\hline Chimenea Creek & 1989 & Chiva & 114 & 4.6 \\
\hline Chimenea Creek & 1999 & Box Canyon & 169 & 6.8 \\
\hline Chimenea Creek & 2003 & Helens II & 9.88 & 0.4 \\
\hline Madrona Canyon & 1994 & Rincon & 427 & 30 \\
\hline Rincon north fork & 1994 & Rincon & 691 & 93 \\
\hline $\begin{array}{l}\text { Rincon upper } \\
\text { central fork }\end{array}$ & 1994 & Rincon & 810 & 73 \\
\hline $\begin{array}{l}\text { Rincon lower } \\
\text { central fork }\end{array}$ & 1994 & Rincon & 810 & 17 \\
\hline Rincon south fork & none & $* * *$ & 0 & 0 \\
\hline
\end{tabular}

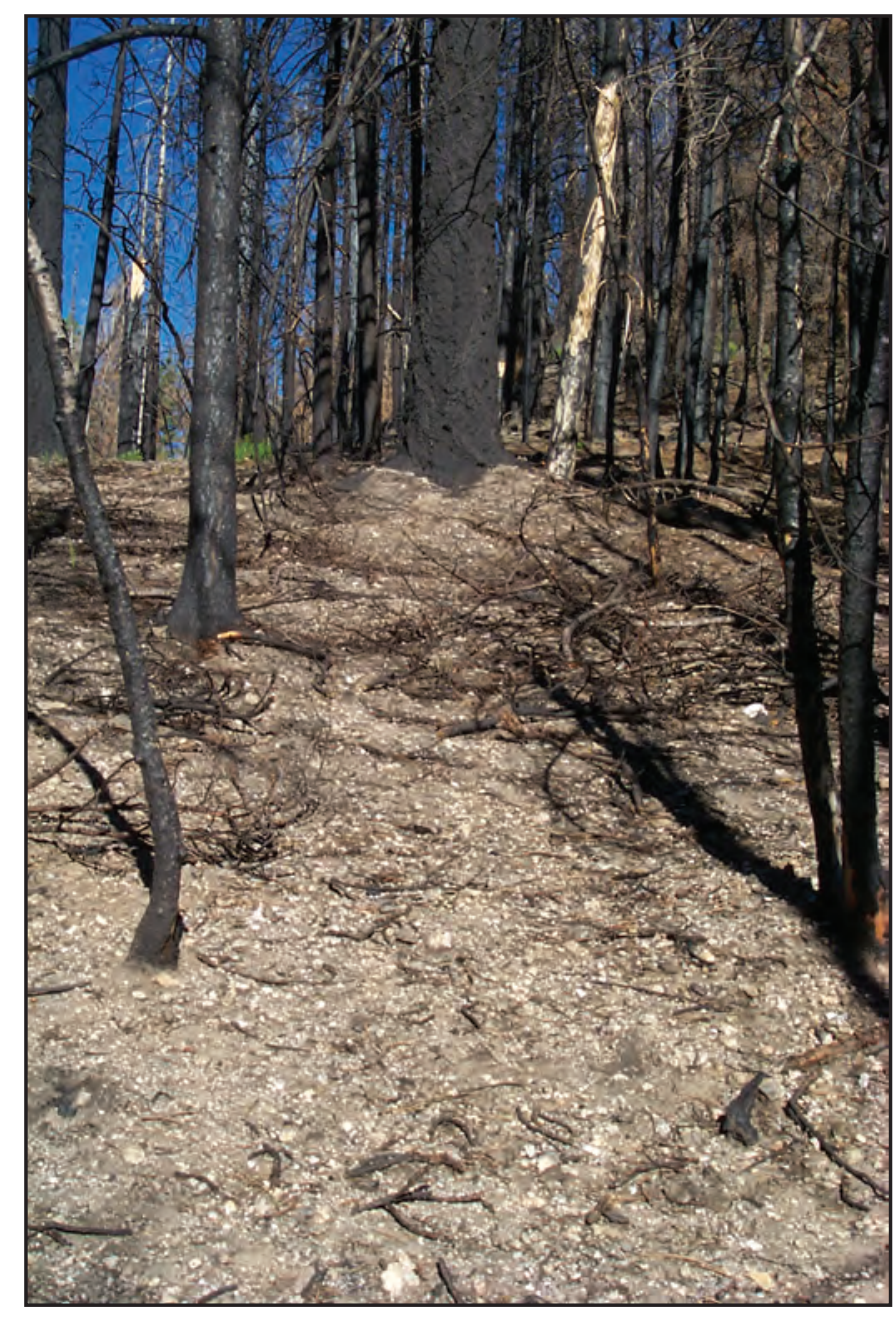

Figure 9. Mixed-conifer forest above the North Slope Trail after the Helens II fire of 2003, Saguaro National Park, Rincon Mountain District, Arizona.

As of spring 2006, 71 percent of mixed conifer and pine forests and about half of oak and juniper woodlands within the Rincon Mountains had been burned at least once since 1989. The only substantial areas of forested watershed that had not been burned by wildfire in the past 60 years included the Chimenea Creek watershed, except near the watershed divide, the western part of Madrona Canyon and the southern Rincon Creek watershed (fig. 1).

\section{Fire management}

Beginning in the 1920s, wildfires were routinely suppressed in the Rincon Mountains, a policy that was typical in most public lands for the next five decades. As a consequence, fuel accumulations and tree densities increased the risk of catastrophic fires and changed the distribution of fire-dependent vegetation (Parsons and Botti, 1996; 
Saguaro National Park, 2004). In 1968, the National Park Service changed its policy of suppressing all fires within its jurisdiction. Some fires were allowed to burn if they contributed to the success of resource management objectives without threatening developed areas or cultural sites. All parks with burnable vegetation are required to have fire management plans that guide fire management activities. These documents are revised as necessary to incorporate new developments in fire management and new findings in fire ecology and to refine management policies to achieve greater success at meeting fire management objectives (Saguaro National Park, 2004).

The current draft fire management statement for Saguaro National Park presents a number of alternatives, most of which involve some combination of selective fire suppression and prescribed burning. The statement acknowledges the role of wildland fire as an essential ecological process and a natural agent of ecological change. The objectives that are related to restoring a more natural fire regimen while protecting park resources are:

- Identify and implement methods to restore and maintain park ecosystems and ecosystem processes that allow fire to play its natural role in the ecosystem, both as wildland fire and prescribed fire.

- Reduce the risk of fire to cultural resources, such as historic buildings and pictographs, through fuels reduction, prescribed burning, or fire suppression.

- Reduce the risk of catastrophic fire, while continuing to reverse the adverse effects from past fire suppression and prevention activities.

Generally, total fire suppression is practiced in vegetation zones that are not fire adapted, in particular within Sonoran scrubland areas and in transition zones where Saguaro cactus are present. Suppression is also required where cultural resources and structures associated with populated areas are at risk. Selective non-suppression of wildfire is practiced in fireadapted vegetation zones, and prescribed burning is practiced in those areas where it can be safely employed to reduce the risk of catastrophic wildfire and to re-establish natural vegetation patterns.

Park managers have employed prescribed burns since 1985 to prevent encroachment of woody vegetation into meadows, to reduce fuel loads and to restore grasslands (Saguaro National Park, 2004). From 1994 to 2004, about 1,263 ha of forested areas in the upper Chimenea Creek watershed have been subject to prescribed burns (fig. 1, table 3), and this treatment may have been a factor in stopping the spread of the Helens II fire into the Manning Camp area.

\section{Sedimentation Processes in the Rincon Mountains}

Sedimentation is the product of physical and chemical geomorphic processes operating on hillslopes and stream channels that make sediment available for transport and subsequently transport it to depositional environments where it is stored for periods of time ranging from hours to millennia. The main factors that control the magnitude and frequency of sediment transport are the intrinsic characteristics of the watershed and the external forces, mainly climatic, operating on the system as well as the recent history of floods, drought, and fire in a drainage basin. Sediment transport data typically are reported as sediment concentration, the mass of sediment per unit of water; sediment discharge, the mass of sediment per unit of stream discharge; sediment yield, the mass of sediment per unit of contributing area over a given time or as sediment flux, the mass of sediment transported through a cross-sectional area over a given time.

Few sediment transport data are available for western watersheds and such data typically are collected over a period of time of a few years to several decades. Consequently, data reported from sediment sampling or from deposition rates in lakes and reservoirs (Meade, 1988) probably give rates of sediment transport well below potential long-term rates. Most sediment is transported from mountain slopes by infrequent, large events that are seldom observed in the generally short period during which sediment transport studies are conducted (Kirchner and others, 2001).

The movement of sediment from hillslopes to channels occurs by slow continuous processes such as soil creep and dry ravel (Selby, 1993; Robichaud and others, 2000) as well as by more rapid, intermittent processes such as rainsplash erosion and sheetwash. Based on field observations, mass movements, such as landslides and debris flows, are infrequent in the Rincon Mountains but evidence of debris flows of several decades to several centuries old occurs in the form of poorly sorted bouldery terraces along stream channels and abundant boulder-sized bedload in small tributaries of moderate gradient. Evidence of rill and gully erosion is scarce even in recent burn areas and seems to be of little significance in other areas.

Soil creep is the slow downslope movement of sediment by gravitational forces, bioturbation and freeze-thaw cycles (Selby, 1993). Field evidence of soil creep is difficult to detect in the Rincon Mountains, but local occurrences of soil slips and hummocky microtopography suggest soil creep is active on some slopes. Dry ravel, the particle-by-particle downslope movement of sediment is widespread in semi-arid mountainlands (Robichaud and others, 2000) and is probably a more significant gravitational process in the cohesionless sand and gravel that cover most hillslopes in the study area. 
Rainsplash, sheetwash, rill and gully erosion are runoffrelated processes, the rate of which depend on the exposure of sediment particles to direct precipitation or surface runoff, as well as the texture and cohesiveness of sediment particles and slope angle. These processes are most active in landscapes with sparse vegetation where little precipitation is intercepted by tree and shrub canopies. Precipitation in well-vegetated areas is stored in leaf canopies and in the layer of organic litter on the ground surface. That water that is not evaporated reaches the land surface slowly enough to be infiltrated into the ground rather than flow over the surface as runoff (Moody and Martin, 2001). Much of the forest canopy within the oak and juniper and juniper and piñon woodlands of the Rincon Mountains is sparse and is non-existent in the desert grasslands and scrublands. Average annual precipitation values in those areas range from 330 to $430 \mathrm{~mm} \mathrm{yr}^{-1}$, which is the range that has been found to produce the highest sediment yields based on nationwide U.S. data (Langbein and Schumm, 1958; Dendy and Bolton, 1976) though these studies looked mainly at agricultural areas.

The mean slope within the park boundary is about 32 percent, but about 70 percent of the slopes are between 35 and 80 percent with less than one percent above 80 percent. In a study of hillslope stability in southern Arizona, Melton (1965) found that 54 percent was the gradient above which granitic hillslopes were unstable though sediment mantles exist at higher slope angles because of irregular bedrock surfaces, vegetation cover, or cohesive, clay-rich sediments in the soil matrix. The low content of fine-grained sediments (particle size $<.0625 \mathrm{~mm}$ ) in the Rincon Mountains (table 2) indicates that hillslope sediments in the study area are nearly cohesionless. The steepest slopes tend to be at the highest elevations. Sediment is stored on hillslopes where it is trapped by obstacles such as tree trunks, fallen logs, understory vegetation and bedrock outcrops and on shallower slopes beneath steep transport slopes. Sediment also is trapped in swales and headwater tributaries where surface flows are infrequent because of the small contributing area above such features.

Once sediment reaches the channel system, it can remain in storage for periods of time ranging from hours to centuries depending on the characteristics of the sediment deposited, the depositional environment and the frequency and magnitude of subsequent stream discharges. The generally patchy distribution of sand in Rincon Mountain channels indicates that the stream channel system generally is supplylimited with respect to sediment with particle size below $2 \mathrm{~mm}$ diameter and is capable of transporting most sand through the system under typical conditions.

\section{Fire, Hydrology, and Geomorphic Processes}

Large, stand-replacing wildfires alter hydrologic processes in ways that can greatly increase the rate of sediment delivery to channels. Increases in storm runoff of 30 to 400 percent are typical following such fires and increases in peak discharges as high as 870 -fold have been reported (Moody and Martin, 2001). The increase in runoff that results from the loss of storage in the forest and scrub canopy and leaf litter can result in extreme increases in sediment load ranging from 4-fold to 220-fold (Veenhuis, 2002; Paige and others, 2003) and sediment flux of 5-fold (Martin and Moody, 2001a) and produce catastrophic debris flows (Cannon and others, 1998, 2001). Severe fires may also decrease the permeability of the upper soil layer to infiltration, thereby further increasing runoff (DeBano, 2000; Martin and Moody, 2001b). At the same time, the exposure of bare soil to the direct impact of rainfall and runoff and the loss of root systems that bind soils to hillslopes increases the amount of sediment available for transport (Florsheim and others, 1991).

Rainfall intensity following wildfire was found to be a key control on peak discharge relations in western mountainous watersheds by Moody and Martin (2001). They found that a 30-minute rainfall of $10 \mathrm{~mm} \mathrm{~h}^{-1}$ represented a threshold above which peak discharge increases at a higher rate than at lower rainfall intensities.

The increased transport of sediment from burned hillslopes can overwhelm the sediment-carrying capacity of a stream. Under normal supply-limited processes in mountain streams, most channel-bottom sediment is mobile and little sediment resides in storage in the channel bottom. Burned watersheds, however, deliver pulses of sediment that can result in excessive deposition in stream channels that overwhelm the streams' transport capacity and result in significant change to channel morphology and hydraulic properties (Moody, 2001). The amount of time the sediment remains stored in the channels depends on the volume of sediment available on hillslopes for transport, the period of time that is required for the conditions to stabilize on hillslopes, the frequency and size of streamflows available for scouring the sediment from the channel, and the physical characteristics of stream channels that govern the velocity of flows through a particular channel reach.

\section{Fire Effects in the Rincon Mountains}

The earliest apparent change in watershed conditions following a major wildfire is a large increase in runoff. The clearest example of this effect in the Rincon Mountains occurred the 1994 Rincon fire that burned about 40 percent of 
the Rincon Creek watershed. From November 1, 1994 to April 30, 1995, the gage station at Rincon Creek recorded a total discharge of 18.99 thousand $\mathrm{m}^{3}$ (fig. 10). Total precipitation at the National Weather Service station at the University of Arizona in Tucson for that period was $204 \mathrm{~mm}$ (National Climate Data Center, 2006). During the same time period, in 1991-92, precipitation totaled $201 \mathrm{~mm}$; however, the cumulative streamflow for that period was 9,863 thousand $\mathrm{m}^{3}$ (fig. 10).

\section{A. Winter 1991-92}

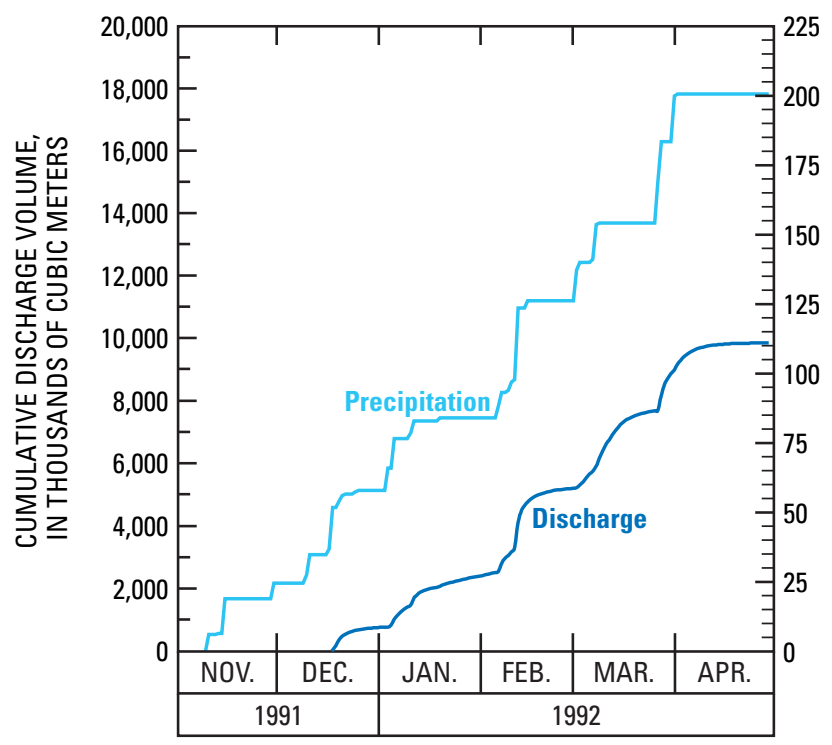

B. Winter 1994-95

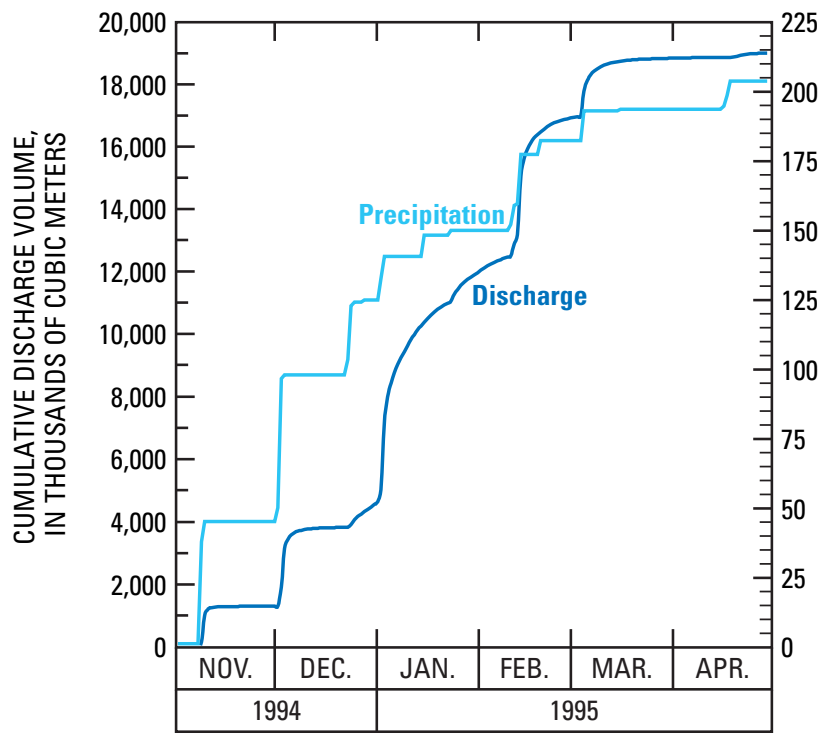

Figure 10. Cumulative daily discharge for Rincon Creek station (09485000) and cumulative daily precipitation at Tucson, Arizona. $A$, Winter 1991-92; $B$, Winter 1994-95.
Actual precipitation values over the Rincon Creek watershed were undoubtedly higher than the totals recorded at Tucson because of elevation effects. Nonetheless, the regional nature of winter storms in southern Arizona likely would produce the same relative values of total precipitation over the watershed as those recorded at Tucson, and the 90 percent runoff increase in discharge in the post-fire winter of 1994-95 is a reasonable value compared with other western watersheds (Moody and Martin, 2001).

Similar increases in runoff have likely resulted from other large fires in the Rincon Mountains, but the gaging stations downstream from the Chiva and Helens II fire on Tanque Verde Creek and downstream from the Box Canyon fire on Pantano Wash have contributing areas that are much larger than the burn areas, and the records were found to be inconclusive.

\section{Effects of Helens II Fire}

In July 2003, just before the inception of this project, the Helens II fire, a hot, runaway wildfire caused by lightning, swept through the Ponderosa and mixed-conifer forests in the Mica Mountain area. Unlike the surface fires that regularly burned the understory with little damage to the forest canopy before the late 19th century, the Helens II fire was a severe, stand-replacing crown fire.

The Helens II fire was particularly severe on the north slope of Mica Mountain in the upper Joaquin Canyon watershed, most of which is located north of the park boundary where it drains into Tanque Verde Creek. Portions of the Canyon del Pino and Chimenea Creek watersheds were also affected.

Observations of post-fire conditions in the burn area were made during 5 field trips conducted in March, June and November 2004, and in July and October 2005. The burn area was accessed from Manning Camp by the trail system that winds through the Spud Rock, Helens Dome and Mica Mountain area (fig. 11). All of the field trips were reconnaissance level surveys in which the main objective was to rapidly assess the mechanisms of sediment transport and changes that occurred over the course of the study period.

Between the containment of the fire on June 30, 2003, and the first field survey in March 2004, about $640 \mathrm{~mm}$ of precipitation was recorded at the rain gage operated by the Pima County Flood Control District at Manning Camp at an elevation of 2,417 m near Mica Mountain. Another $98 \mathrm{~mm}$ fell before the next survey in June 2004. Those totals are near average annual precipitation values for the upper elevations of the Rincon Mountains (Bowers and McLaughlin, 1987). Two storms with precipitation intensities greater than $10 \mathrm{~mm}$ $\mathrm{hr}^{-1}$ that lasted a half hour or more occurred during the monsoon season following the fire in summer 2003 (table 4). 


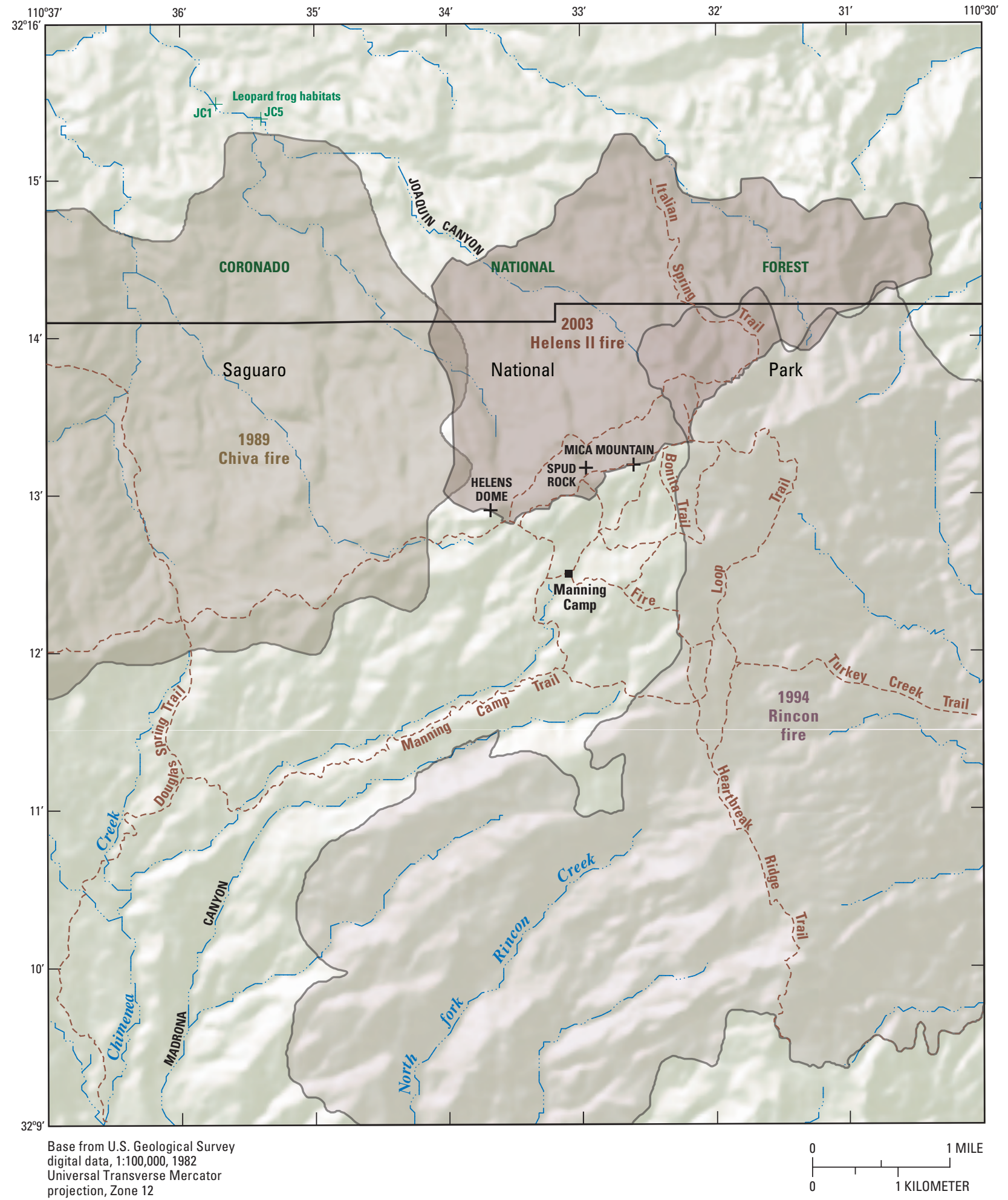

Figure 11. Helens II burn area and Joaquin Canyon, Saguaro National Park, Rincon Mountain District, Arizona. 
Table 4. Highest intensity storms occurring after the Helens II fire recorded at Pima County Flood Control precipitation gage 4100 at Manning Camp,Saguaro National Park, Rincon Mountain District, Arizona, 2006)

$\left[\mathrm{mm} \mathrm{hr}^{-1}\right.$, millimeters hour]

\begin{tabular}{cccc}
\hline Date & $\begin{array}{c}\text { Length of } \\
\text { storm } \\
\text { (hours) }\end{array}$ & $\begin{array}{c}\text { Total } \\
\text { precipitation } \\
\text { (millimeters) }\end{array}$ & $\begin{array}{c}\text { Rainfall } \\
\text { intensity } \\
\text { (mm hr } \mathbf{~}^{\text {) }}\end{array}$ \\
\hline $07 / 12 / 2003$ & 0.65 & 16.0 & 24.7 \\
$07 / 20 / 2003$ & 1.84 & 27.2 & 14.8 \\
$08 / 05 / 2004$ & 1.52 & 30.0 & 19.7 \\
$08 / 09 / 2004$ & .77 & 25.9 & 33.6 \\
$08 / 11 / 2004$ & 1.18 & 15.0 & 12.7 \\
$07 / 17 / 2005$ & .51 & 14.0 & 27.0 \\
$08 / 07 / 2005$ & 1.11 & 12.2 & 11.0 \\
$09 / 07 / 2005$ & 1.95 & 21.8 & 11.2 \\
\hline
\end{tabular}

During the summer and fall of 2004, $236 \mathrm{~mm}$ of precipitation was recorded with three high intensity storms in August (table 4). Between the field surveys of November 2004 and July 2005, $458 \mathrm{~mm}$ precipitation was recorded at Manning Camp, mainly during low intensity winter storms, and between the July and late October 2005 field surveys another $226 \mathrm{~mm}$ of precipitation fell. Three high intensity storms occurred in the summer of 2005 (table 4).

In the area of greatest burn severity along the north slope of Mica Mountain and on the east slopes of Spud Rock, large patches of forest were totally destroyed (figs. 9, 11). Swaths of trees, standing and fallen, were completely blackened and the organic forest floor layer had been completely consumed by the fire though a new layer of dead conifer needles covered areas where the crowns had not been consumed in the fire. The exposed soil surface on hillsides in the Helens II burn area showed abundant evidence of erosion by overland flow including splays of sand and gravel and erosional pillars about $2-3 \mathrm{~cm}$ in height (fig. 12A). In general, rills were sparsely distributed, poorly formed and discontinuous and were seen mainly on slopes in finer-grained forest soils with gradients above about 60 percent. Typical rills were $10-30 \mathrm{~cm}$ wide and less than $5 \mathrm{~cm}$ deep. Little gully erosion had occurred; however, there was abundant evidence of weakly channelized flow (fig. 12B) and scouring of sediment from swales and headwater channels (fig. 12C). There was some evidence of debris flows, mainly coarse overbank and channel deposits in headwater tributaries of Joaquin Canyon (fig. 12D). By far, the most extensive process of sediment transport from hillslopes appeared to be the result of a combination of rainsplash erosion that resulted in winnowing of finer-grained sediment, mainly sand, from the poorly sorted, stony hillslope sediments and the subsequent downslope transport of the material by unchannelized and weakly channelized flow. There was no evidence of hillslope erosion to depths of greater than about $15 \mathrm{~cm}$ on the slopes and most evidence suggested that erosion depths were more commonly restricted to 2-3 $\mathrm{cm}$. The absence of deep gullies or landslide scars indicates that sediment was moved downslope mainly by surface flow rather than being entrained as a mass. This sediment transport mechanism is characteristic of burned watersheds where the rapid delivery and accumulation of surface water to the bare ground surface and consequent increased runoff results in minimal infiltration into the soil layer (Wells, 1987; Cannon and others, 1998; 2001).

Although there were numerous patches of unburned or lightly burned forest, evidence of sediment transport through those areas, such as strings and splays of sediment, were abundant, indicating that runoff from burned areas upslope had transported sediment into the unburned sections. On some slopes beneath unburned forest, the ground surface exhibited a hummocky microtopography suggestive of soil slips (Selby, 1993 ). The fresh appearance of the broken soil surface indicated the recent origin of the soil slips. An acceleration of soil creep could have resulted from an increase in runoff from burned slopes near the top of ridge crests that infiltrated into the soil as it entered the unburned forested areas.

Little change was evident on hillslopes in the intervals between the 2004 field trips even though there were three high-intensity storms in August 2004 (table 4). One change that was noticed during the survey of November 2004 was the degradation of the North Slope Trail (fig. 11) that had occurred since the surveys of March and June. The trail had been generally easy to navigate during the earlier surveys, but by November many sections of the trail had become difficult or impossible to follow. Only a few sections of trail were washed out by gully erosion, but large sections had become indistinct as a result of the rounding of trail edges by sheetwash erosion, widespread deposition of sediment on the trail and the subsequent intrusion of vegetation.

The nature of sediment erosion from the Rincon Mountain hillslopes, namely the diffuse nature of rainsplash, sheetwash, and soil creep made assessment of change from repeated observations difficult. The effect of such processes is to redistribute sediment particles on the hillslopes without causing obvious changes in hillslope appearance. Subtle changes include coarsening of the ground surface where finergrained sediments have been winnowed out of the soil matrix and transported downstream and the variation in slope and surface roughness as the particles are transported, stored, and transported again toward the channels at the base of the slopes. These are normal sedimentation processes in the Rincon Mountains that are accelerated as a result of the changed hydrologic conditions immediately following a wildfire. Measurement of the magnitude of changes in hillslope erosion resulting from wildfire-induced hydrologic change requires detailed monitoring that was beyond the scope of this study. 
A. Erosion pillars created by sheetwash

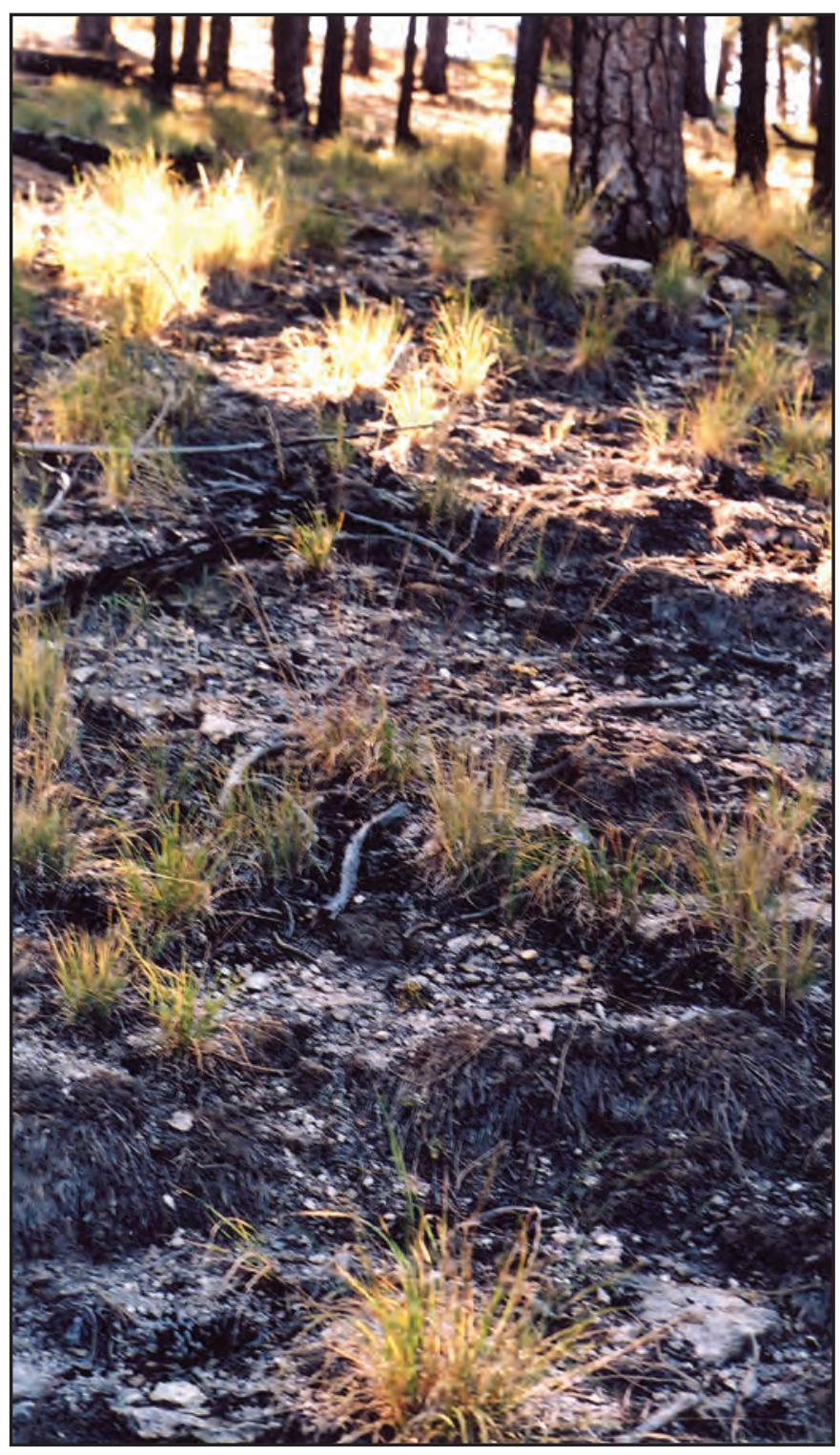

$B$. Weakly channelized flow on burned hillslope

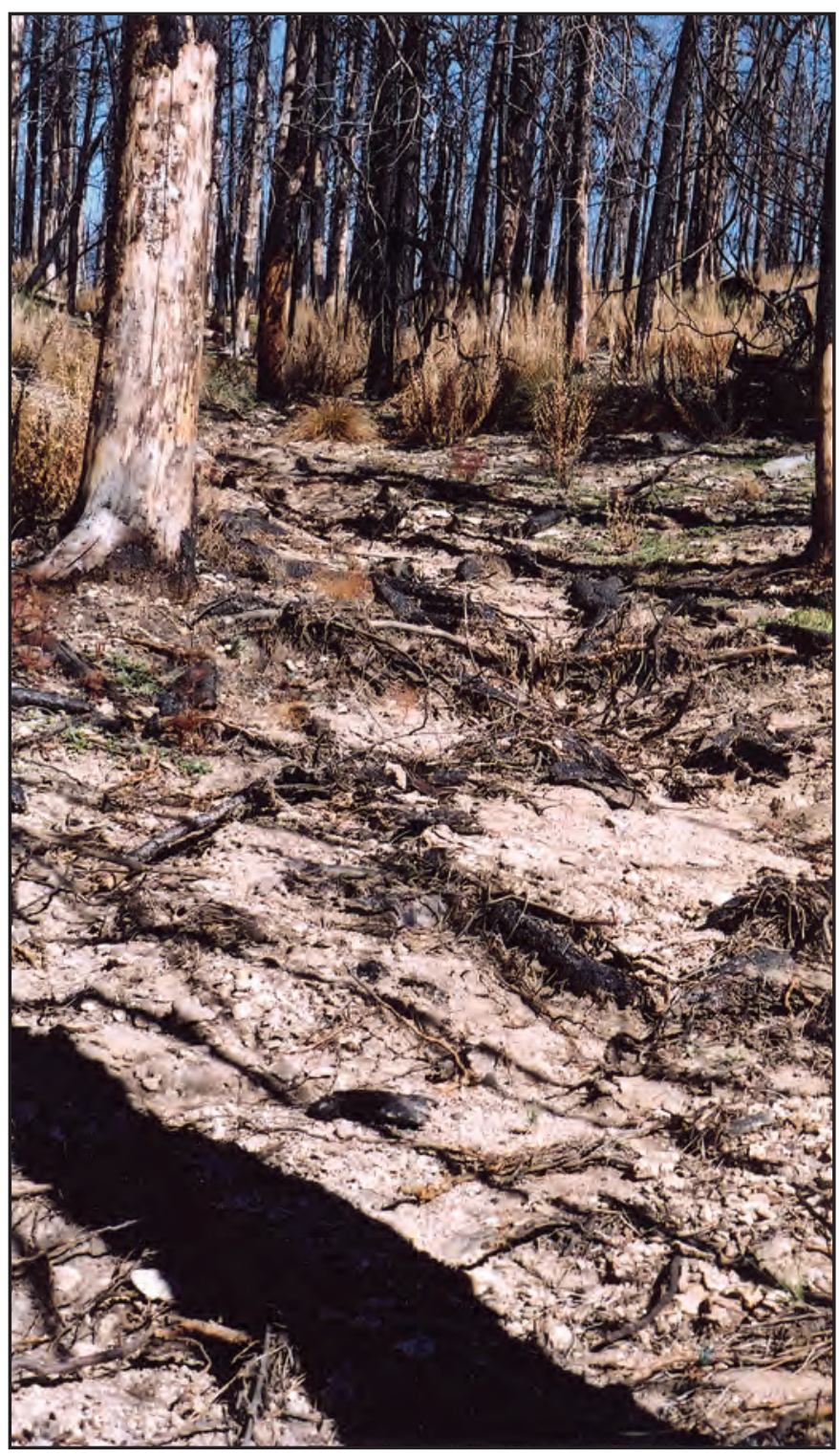

Figure 12. Post-wildfire erosion mechanisms, Saguaro National Park, Rincon Mountain District, Arizona. A, Erosion pillars created by sheetwash; $B$, Weakly channelized flow on burned hillslope; $C$, Boulder lag in scoured swale; $D$, Coarse, poorly sorted, post-wildfire overbank deposits in Joaquin Canyon tributary. 


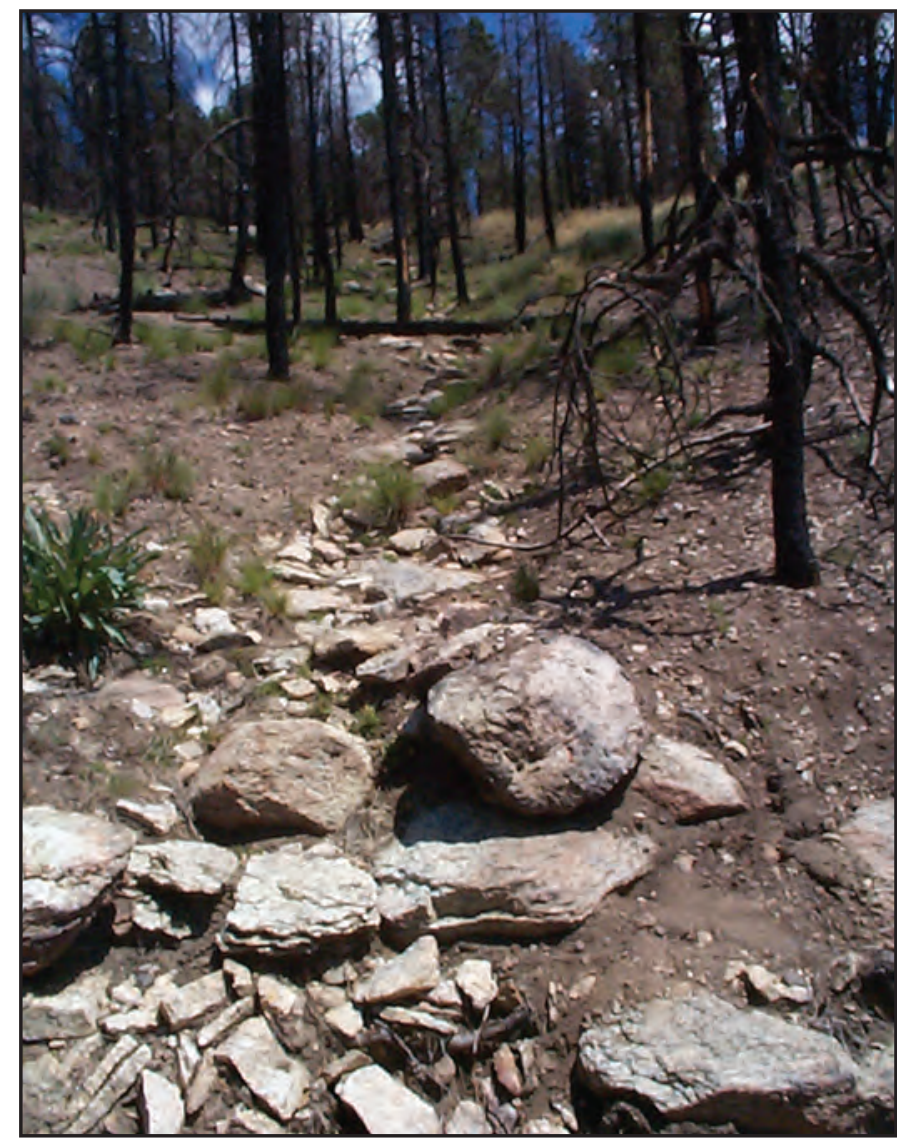

\section{Boulder lag in scoured swale}

$D$. Coarse, poorly sorted, post-wildfire overbank deposits

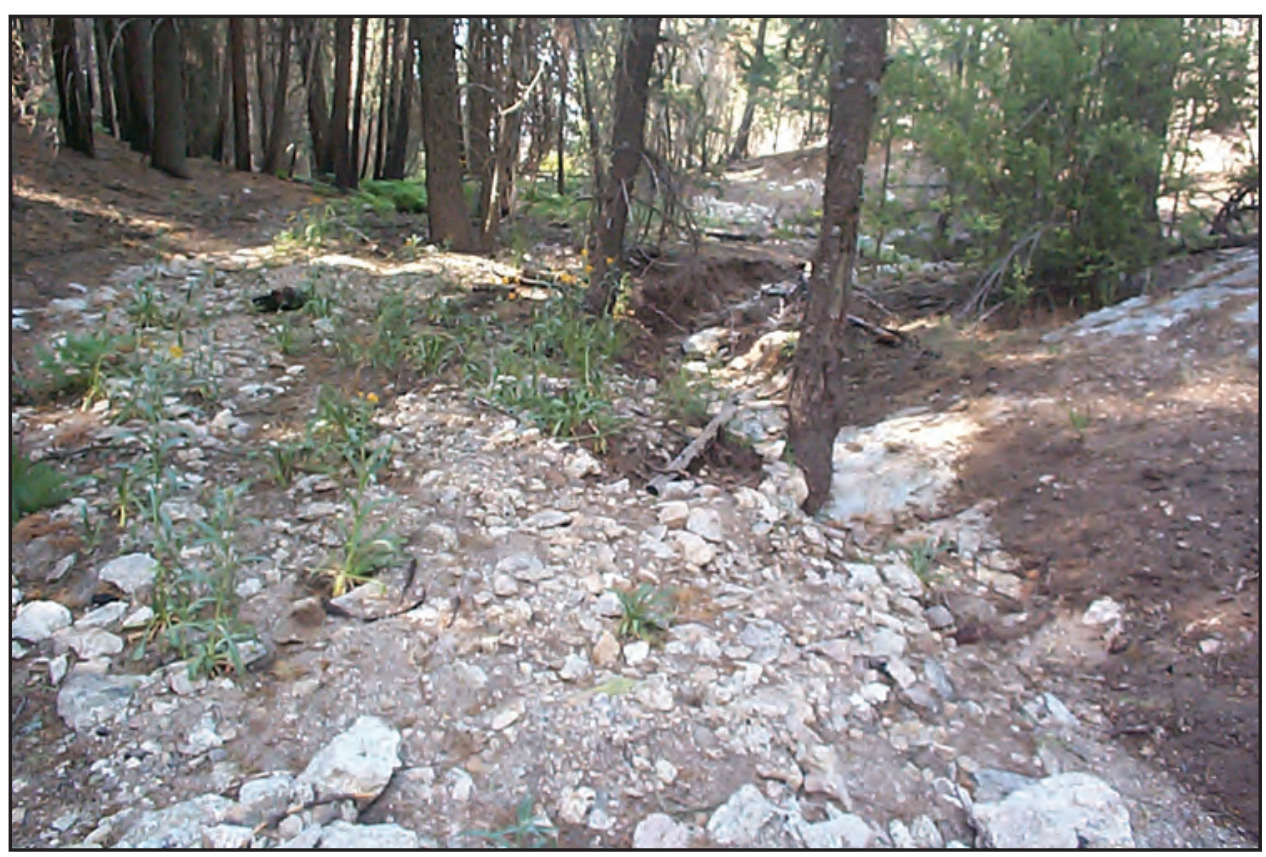

Figure 12. Continued. 
By the time of fourth and fifth field trips to the burn area in July and October 2005, little evidence was seen of additional erosion from hillslopes except for an occasional rill that had been evacuated of all sediment above a cobblearmored bottom. Such rills were scarce; however, and the maximum depth of incision typically was about $15 \mathrm{~cm}$. Movement of sediment was apparent in the appearance of charcoal-laden sediment in unburned forest areas and the deposition of sediment on the upslope side of tree trunks, stumps and newly sprouted vegetation, particularly stands of bracken fern (fig. 13A). Surface roughness had increased on many slopes as a result of new vegetation growth and the accumulation of fallen trees and broken branches from the stands of burned forest, and slopes that were still barren typically were armored with gravelly lag (fig. 13B). Though much of the burned area looked as raw as it had appeared in the first year after the fire, the patchy recovery of the hillslopes was clearly taking place by revegetation and exhaustion of the available sediment supply. The effects of this partial recovery on the rate and magnitude of hydrologic processes could not be measured for this study, but in other studies in western mountain areas, runoff and sediment transport returned to prefire levels within two to seven years (Bolin and Ward, 1987; Moody and Martin, 2001). In New Mexico, however, Veenhuis (2002) found flood magnitudes remained elevated 22 years after a fire in Bandelier National Monument.

\section{Effects of Earlier Fires}

In cursory surveys of parts of the Chiva, Box Canyon, and Rincon burn areas, virtually no evidence was found that could be unequivocally attributed to wildfire. Although vegetation had not fully recovered in many areas where burned snags were the tallest vegetation features in the landscape, ground cover appeared as dense as in unburned areas. Evidence of sheetwash erosion was sparse and could easily have occurred well after the fires. Six years had passed since the Box Canyon fire, the most recent of the fires, and the recovery of the watershed is not surprising in light of recovery times of three to seven years reported for other western watersheds. Because only a small fraction of the older burn areas were surveyed, especially in the Chiva and Rincon burn areas, it is possible that evidence of continuing post-fire effects in those areas were overlooked.

Although revegetation is perhaps the most important factor in watershed recovery, depletion of sediment supply in the first year or two following the fire is also likely a factor (Bolin and Ward, 1987) and some part of the recovery may be due to the armoring of surfaces by gravel lags that result from the winnowing of finer material from the soil matrix. Sediment samples MMH1 and MMH2 (fig. 13B, table 2) were taken from the upper $2 \mathrm{~cm}$ and the lower $10 \mathrm{~cm}$ of the ground surface on a hillslope in the Helens II burn area. The upper layer is slightly coarser than the lower layer, suggesting possible winnowing of fine material from the surface though a single sample is hardly conclusive evidence. Poesen and others (1999) found that rock fragment cover significantly reduced concentrated flow erosion rates, but the reduction was considerably greater for initially wet soils than for initially dry soils. This would indicate that any erosion protection provided by a gravel lag might be more effective during winter storms and later summer storms than for the initial storms of the monsoon season.

\section{Fire Effects on Channels and Tinajas}

The effects of post-wildfire sedimentation on the channel system within and below the burn area were more easily observed than hillslope processes. Within the burn area, headwater channels of Canyon del Pino, Chimenea Creek, and Joaquin Canyon contained a bedload of poorly sorted, charcoal-rich gravel and sand and isolated occurrences of finegrained ash-laden sediments in 2004. By fall 2005, however, coarse overbank deposits and subsequent channel incision in the headwaters of Joaquin Canyon tell of an initial pulse of hillslope sedimentation followed by scouring streamflows (fig. 12D). Sand and finer-grained sediments also had been flushed from Canyon del Pino and Chimenea Creek, leaving behind a clean, cobbly gravel bed. The change in channel conditions in the headwaters of these streams between summer of 2004 and 2005 is further evidence that sediment transport from the slopes of the burn area to the channels had greatly slowed in that time period while stream flows were sufficiently high to move sand and fine gravel downstream.

A $3 \mathrm{~km}$ reach of Joaquin Canyon upstream from its confluence with Tanque Verde Creek (fig. 11) was surveyed three times in the course of this investigation. All of this reach is located north of the park boundary in the Coronado National Forest. There are two major tinajas within this reach both of which were known to have been at least temporarily occupied by leopard frogs. The first survey was conducted in June 2004. A veneer of gray sediment that appeared to be nearly 100 percent ash was found in scattered patches in the cobbly to bouldery gravel channel bottom that characterizes the lowest $1,300 \mathrm{~m}$ of the channel. Although this material constitutes the first flush of sediment from the burned watershed and is readily transported by most stream discharges, it is preserved along channel margins as a cohesive crust that apparently persists during subsequent periods of precipitation and streamflow.

The lowest tinaja, pool JC1 (figs. 11, 14A) is about $10 \mathrm{~m}$ long and $5 \mathrm{~m}$ wide that at the time contained water to a depth of about $50 \mathrm{~cm}$. The margins of the pool are alluvial and appear to be the eroded edges of a terrace that borders the east and west edges of the pool. The bottom of the pool was covered with black fine-grained mud of an unknown depth. Between that pool and Chiva Falls, about 500 m upstream, the channel bed was mainly bedrock with coarse alluvium of cobble to boulder size and patchy deposits of coarse sand. The base of Chiva Falls consisted of large sand-filled basin of unknown depth. Above the falls, a smooth bedrock reach of about $380 \mathrm{~m}$ length contained several small pools with only a light covering of fine sand and silt and organic ooze on the bottom. Above that reach, the channel was filled with a chaotic jumble of boulders as much as $3 \mathrm{~m}$ in diameter interspersed with gravelly alluvium and patchy coarse sand. The next large tinaja, pool JC5 (fig. 11) located about $620 \mathrm{~m}$ above Chiva Falls also contained water, but about $1 \mathrm{~m}$ of black mud (sample JQ1, table 2) had been deposited along its east margin since it had last been surveyed by park staff on July 3, 2003. 
When lower Joaquin Canyon was again surveyed in June 2005, little change was seen at the lowest tinaja, pool JC1 (fig. 14A) except that the fine-grained sediment that had covered the bottom during the first visit had been removed and replaced by a thin, patchy layer of sand over a bedrock surface. Despite the earlier deposition of ash, four adult leopard frogs and one Sonoran mud turtle were observed in the pool during the second survey. The pools immediately above Chiva Falls were in much the same condition as in the previous survey, but pool JC5 had been partially filled with sand and gravel to an estimated depth of 0.5 to $1 \mathrm{~m}$. (figs. 11 ,
14B; sample JCP11, table 2). At the time, that tinaja was the downstream limit of thick sand deposits, but by the time of the final survey in October 2005, thick deposits of sandy gravel had been deposited throughout the bouldery reach below pool JC5 for a distance of about $400 \mathrm{~m}$ downstream. The sand deposits ended abruptly at that point. The survey continued upstream another $750 \mathrm{~m}$, where 7 more tinajas were examined, most of which had some sand deposition of varying degree but none were completely full. At the downstream end of Joaquin Canyon, the channel was an essentially sand-free gravel-bed channel at the time of the last survey (fig. 14C).

\section{$A$. Revegetation two years after the fire}

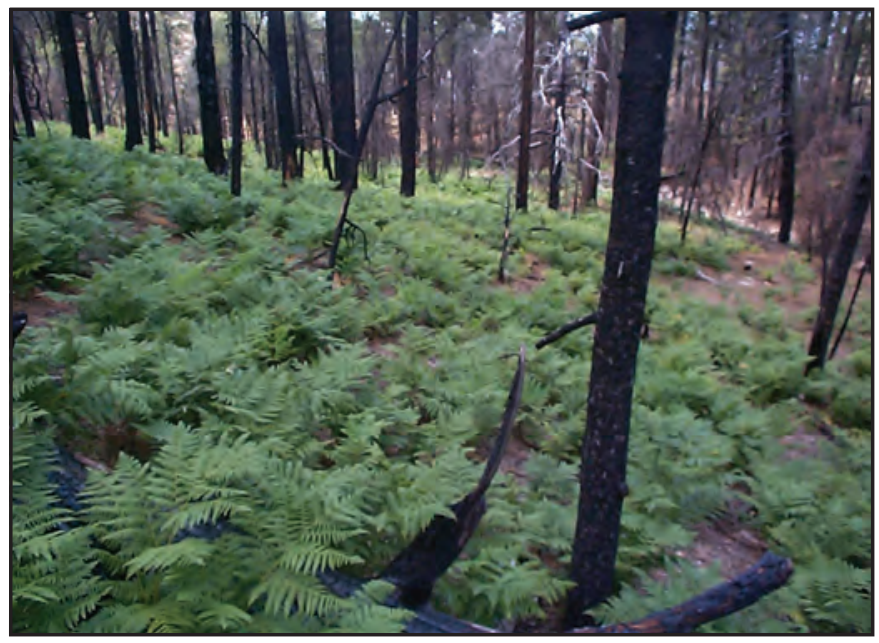

\section{$B$. Formation of coarse gravel lag}

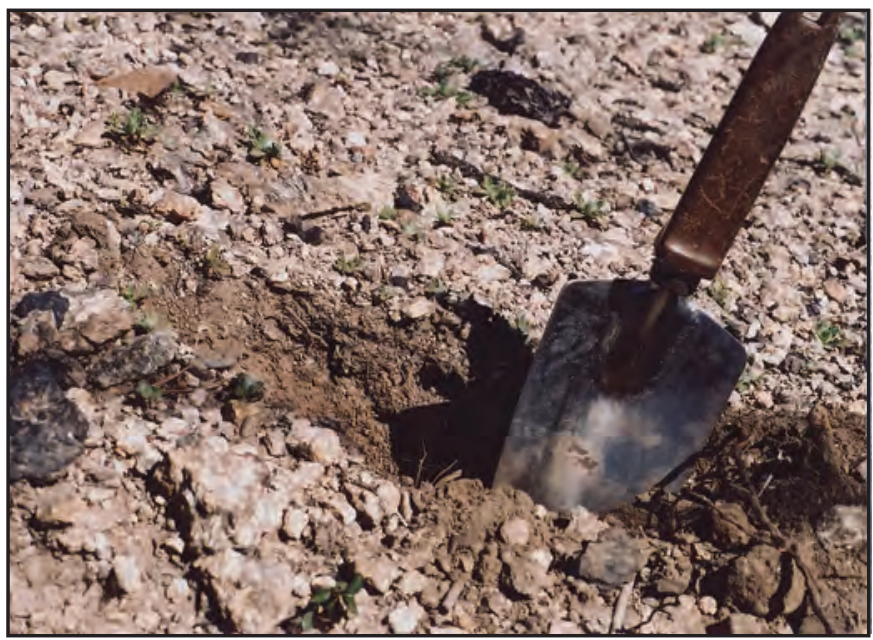

Figure 13. Stabilization of hill slopes in Helens II burn area, Saguaro National Park, Rincon Mountain District, Arizona. $A$, Revegetation two years after the fire. $B$, Formation of coarse gravel lag above finer soil matrix.

\section{A. Pool JC1}

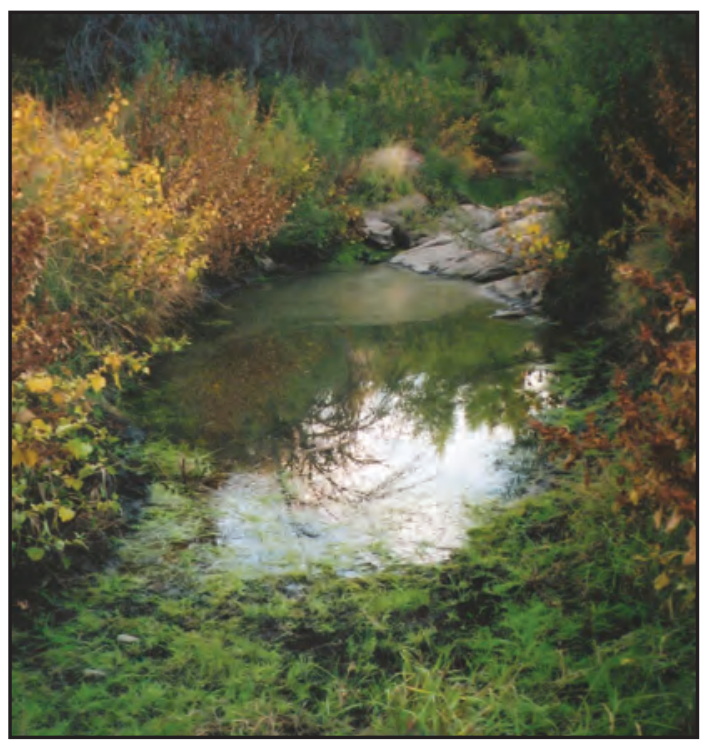

B. Pool JC5

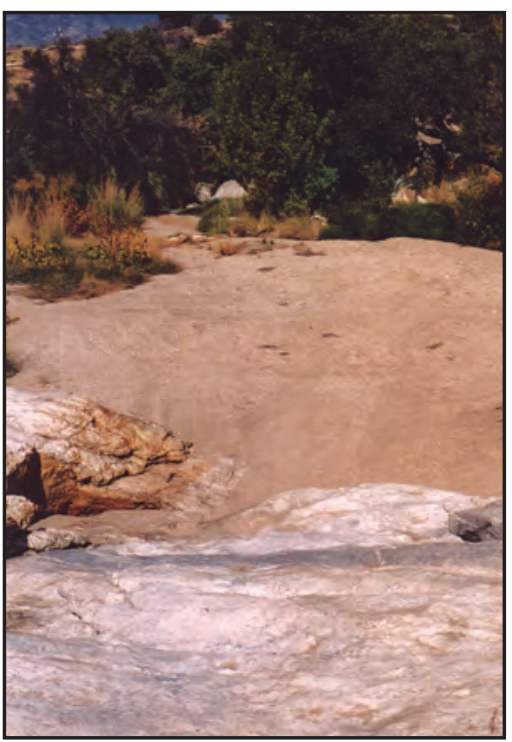

C. Downstream end of Joaquin Canyon

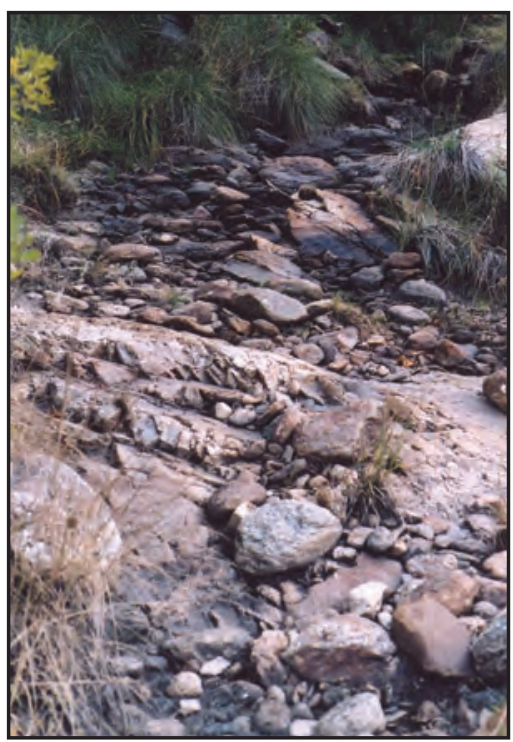

Figure 14. Joaquin Canyon tinajas and channel in October 2005, Coronado National Forest, Arizona. A, Pool JC1; $B$, Pool JC5; $C$, Downstream end of Joaquin Canyon near Tanque Verde Creek. (Photograph for fig. 14A from files of National Park Service, Saguaro National Park, Rincon Mountain District.) 


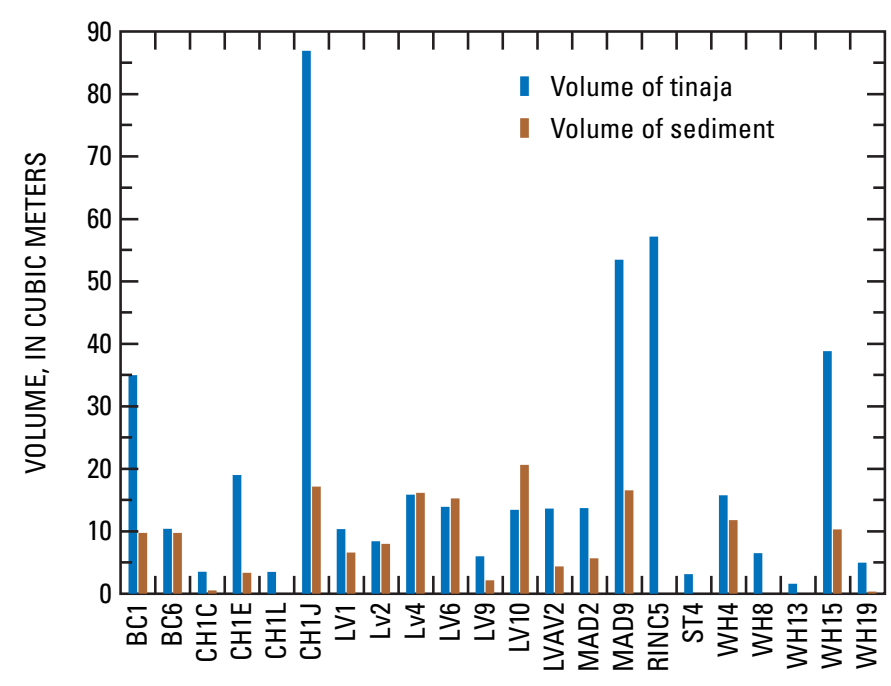

SITE CODE (See fig. 3 and table 4)

Figure 15. Volume of tinajas and volume occupied by sediment in channels of Rincon Mountains, 2005-06, Saguaro National Park, Rincon Mountain District, Arizona.

Deposits in the lower Joaquin Canyon channels appeared similar to those seen in Loma Verde Wash. The sand deposits were well-sorted relative to the channel bed material and probable debris flow deposits that were seen in the upper tributaries.

\section{Sedimentation History and Processes}

Channel recovery has taken considerably longer to occur than watershed recovery, at least in the case of Loma Verde Wash, below the Box Canyon fire of 1999. The history of Loma Verde Wash following the fire has been well-documented in the course of park service monitoring of leopard frog habitat since 1996. The first slug of sand and gravel that inundated the uppermost tinajas arrived a few months after the fire and within two years all of the tinajas had been filled with 1-2 $\mathrm{m}$ of sand. The subsequent desiccation of the pools eliminated what was then one of the highest concentrations of leopard frog habitat in the park (unpublished data, Saguaro National Park). At the beginning of summer 2005, sediment still filled all of the tinajas in Loma Verde Wash; however, sand storage generally was sparse in channel reaches between pools. In October 2005, evidence of about $50 \mathrm{~cm}$ of scour was observed in pool (LV5 (fig. 3) where the highest sediment level was demarcated by a line of sand on the face of a rock that formed the downstream edge of the pool. Before that, no indication of scour had been reported since the pools had filled with sediment. Further upstream in a smooth bedrock reach, a number of small pools were seen, only one of which was filled with sand. Finally, two tinajas that were excavated by a crew of volunteers in May 2005 did not refill with sediment during the monsoon season. These observations seemed to point to the possibility that the supply of sediment readily available for transport into lower Loma Verde Wash had been significantly depleted; however, heavy monsoon rains in summer 2006 buried the excavated pools once again (personal communication, Don Swann, biologist, Saguaro National Park, August 2006).

Comparison of sedimentation history in channels other than Loma Verde Wash and Joaquin Canyon is hampered by the absence of systematic observations. Although most tinajas in Box Canyon, Chimenea Creek and the north fork of Rincon Creek that were visited in the reconnaissance surveys conducted in this study were not filled with sediment, every channel contained a few pools that were nearly filled.

From July 2005 to April 2006, volunteers and park staff conducted surveys of 23 tinajas in seven stream channels to measure pool dimensions and probe sediment deposits to determine depth of sedimentation and volume of the deposits (fig. 15, table 5). Tinajas in Loma Verde Wash contained highest volumes of sediment per pool volume with three of the seven pools sampled having 100 percent or greater of pool capacity filled with sand and gravel. The mean volume of pool capacity occupied by sediment for the Loma Verde pools was 81 percent, compared to 17.3 percent for the remaining 16 pools. Pools LV1 and LVAV2 had been artificially excavated before this survey. Both pools were approximately 100 percent filled at the time they were excavated. Wildhorse Canyon was the only other channel in which a tinaja was sampled that was more than 50 percent filled with sediment (pool WH4, figs. 3, 15; table 5).

Tinajas serve as the site of sediment storage that is longterm relative to that stored elsewhere in the active channel. Of the tinajas that have been sampled to determine sediment volumes, those below older burn areas or lightly burned areas were not completely filled with sediment. The difference between the percentage of fill in these pools and that in the Loma Verde and the upper tinajas of Joaquin Canyon gives some indication of the great difference in sediment flux between those affected by recent, severe wildfires and those that are not.

Beneath newly burned areas, the slug of sediment that ultimately fills the tinajas moves episodically downstream, probably in response to intense but short-lived periods of runoff generated by isolated thunderstorms. In Joaquin Canyon, the sediment slug that buried JC5 (fig. 11) was delivered from sources a minimum of $3.3 \mathrm{~km}$ and up to $6.3 \mathrm{~km}$ upstream. The influx of fine-grained, ash-laden sediment that occupied the pool in June 2004 probably was transported to the pool during the first episodes of significant runoff in the monsoon season after the fire. The first pulse of sandy gravel that eventually buried the pool did not arrive until sometime between June 2004 and June 2005, probably after the three intense storms of August 2004 (table 4). Between June and October 2005, the sediment front had filled the pool and moved only another $400 \mathrm{~m}$ downstream despite three storms with rainfall intensities greater than $10 \mathrm{~mm} \mathrm{hr}^{-1}$ that lasted 30 minutes or more. The sediment wave that buried the Loma Verde tinajas was transported at a similar leisurely pace and did not fill the lowermost tinajas until two years after the Box Canyon fire. 
A. Before fire

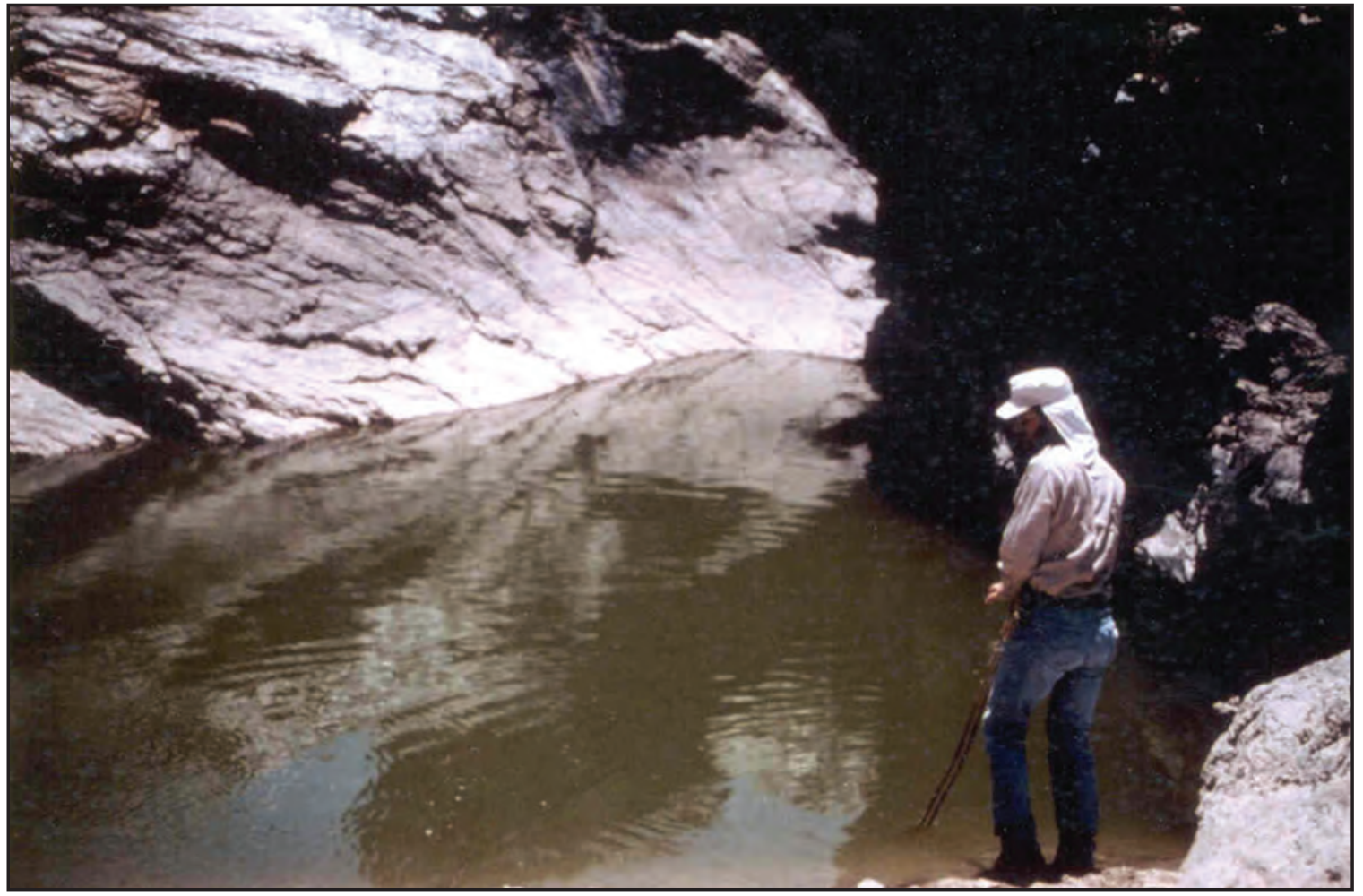

\section{B. After fire}

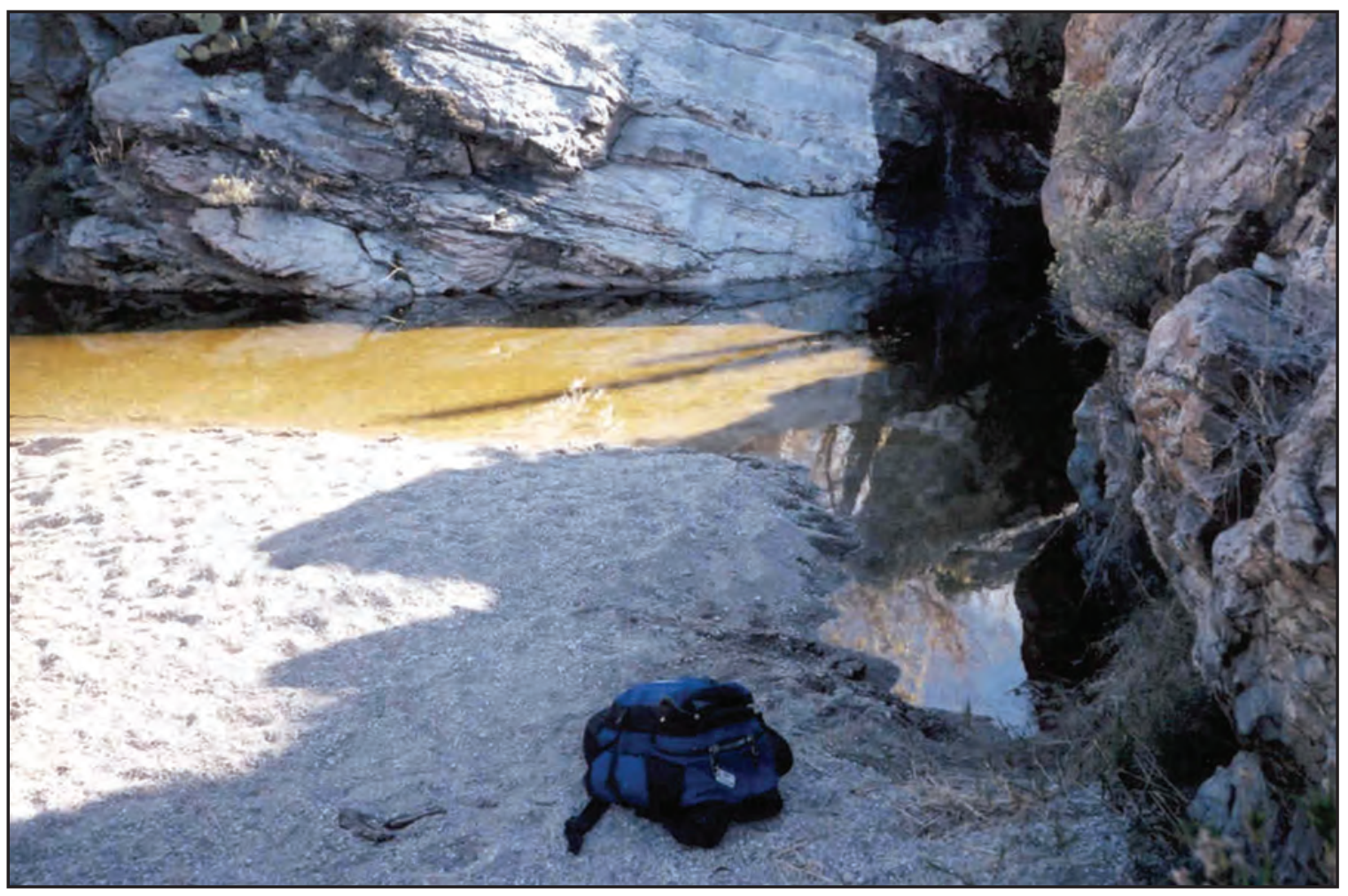

Figure 16. Tinaja in Wildhorse Canyon, Saguaro National Park, Rincon Mountain District, Arizona. A, Before Chiva fire of 1989; $B$, After Chiva fire. (Photo from files of National Park Service, Saguaro National Park, Rincon District, Arizona.) 
Table 5. Pool volume and volume of sediment for tinajas surveyed in 2005-06, Saguaro National Park, Rincon Mountain District, Arizona.

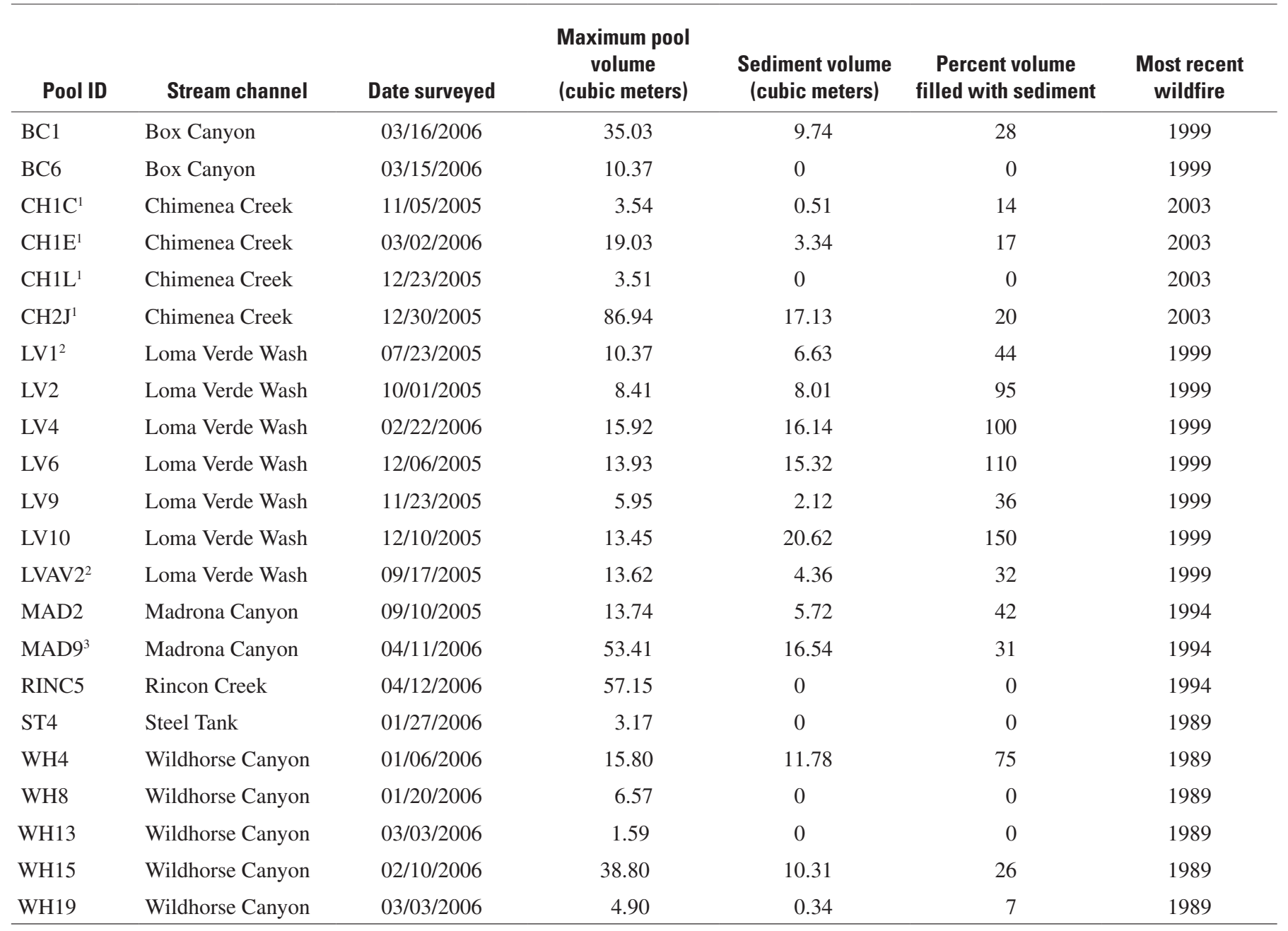

${ }^{1}$ Less than 1 percent of watershed above tinaja was burned.

${ }^{2}$ Pool was excavated May 25, 2005, and had not refilled at time of volume measurements.

${ }^{3}$ Less than 10 percent of watershed above tinaja was burned.

Transport of the sandy gravel into the lower reaches of Joaquin Canyon and Loma Verde Wash probably occurred as a series of debris flows or hyperconcentrated streamflows formed by the seasonal remobilization of sediment stored in the channel following earlier flows. The large volume of sediment relative to normal sediment loads in the Rincon Mountains, the abrupt arrival of the large sediment slug, the texture of the deposits and the occurrence of intense monsoon storms between transport episodes suggests such a mechanism. Some of the characteristics of debris flow deposits described in the literature, such as natural levees and coarse gravel lobes (Cannon and others, 2001) were not observed, but the deposits in Joaquin Canyon downstream from tinaja JC5 (fig. 11) resemble those described by Florsheim and others (1991) and Wohl and Pearthree (1998) in that they were confined to the channel and consisted primarily of fine gravel and coarse sand. Although there was little evidence of significant transport of boulders and large cobbles out of the headwaters, Cannon and others (2001) describe debris flows in which large particles are deposited in uppermost reaches and finer material continues to be transported downstream.

The residence time of sediment stored in a tinaja will vary with the supply of sediment to the reach in which it is located, the magnitude and frequency of discharge, and the morphology of the pool. The last factor may account for the persistence of stored sediment in some pools that have remain filled long after they were buried as a result of postwildfire sedimentation. High volumes of sediment remain in many of the tinajas of Loma Verde Wash, 7 years after the Box Canyon fire, and even in some pools in Wildhorse Canyon, 17 years after the Chiva fire. In Wildhorse Canyon, one tinaja for which sediment storage was measured was 75 percent filled with sediment, the fifth highest percentage of the 23 tinajas surveyed (WH4, fig. 15, table 5). Another 
large tinaja in Wildhorse Canyon that was discovered to have filled with sediment by 1991 was still buried as of 2006 (fig. 16). The tinajas that have had persistent sediment storage have tended to be those that are formed by obstruction of stream flow by bedrock outcrops, sills, or boulders (fig. 17A) or tinajas that are wider and deeper than the channel that enters it so that streamflow velocities are damped as the flow enters the pool. Tinajas, such as potholes and crevices in smooth, fluted bedrock reaches, that were formed as a result of high-velocity, abrasive, sand-laden flows are more likely to be subject to scouring of sand previously deposited during waning flows (fig. 17B).

Although the sedimentation history of Wildhorse Canyon is not as well documented as that of Loma Verde Wash, park staff have noted high volumes of sediment in some tinajas, especially in the lowest reaches of the channel (personal communication, Don Swann, biologist, Saguaro National Park, 2006). These observations are supplemented by leopard frog monitoring records maintained from June 1996 to January 2006 (unpublished data, Saguaro National Park). Only one leopard frog sighting in Wildhorse Canyon was recorded through 1997 and five more were recorded through 1998. All of the sightings but one were recorded in the two tinajas at the downstream end of the channel. By the end of 2000, 15 additional adult leopard frogs had been sighted, all but two in tinajas located in the upper channel upstream from pool WH8 (fig. 3). Another 38 sightings were reported in 2001, all of which were in the upper reaches above pools WH12 to WH19. Sightings became increasingly more frequent and by January 2006, there had been 297 adult frog observed, only 16 of which were found in tinajas downstream from WH8. Sightings were reported as far upstream as WH39.

Leopard frog observations are problematic data for inferring sedimentation processes because of multiple environmental factors that can cause fluctuation in frog populations and because observation conditions, such as water clarity, algae growth, and vegetation cover along tinaja margins, vary from one visit to another. Nonetheless, the presence of high sediment volume in the lower reaches reported anecdotally and by measurement of sediment volume (fig. 15, table 5) suggests that the distribution of leopard frogs in the 17 years following the Chiva fire has been affected by persistent, high volumes of sediment in pools.

The sedimentation history of the channels draining the west side of the Rincon Mountains into Pantano Wash is sketchy. A one-day survey of Box Canyon in July 2005 was conducted to see how conditions compared to those in Loma Verde Wash. About 61 percent of the watershed was burned in the Box Canyon fire of 1999 (fig. 1, table 3). Sand deposition was variable throughout the $3.6-\mathrm{km}$ reach that was surveyed. Two pools were nearly filled with sediment, but most had little to no sand and more than half contained water ranging from 0.5 to $1 \mathrm{~m}$ depth. The extent of maximum post-wildfire deposition is not known. Near the upstream end of the survey, the eroded remnant of ash deposits were found at the edge of the channel, indicating that Box Canyon received the initial flush of sediment from the burned watershed. Park staff; however, reported that the lower tinajas had not been filled with sediment following the Box Canyon fire as was the case with Loma Verde Wash. Tinajas BC1 and BC6 (fig. 3) were surveyed in winter 2005-06 and contained 9.7 and 0 percent sediment volume respectively (fig. 15, table 5). Only one adult leopard frog has been sighted since the 1999 fire, which might suggest some post-wildfire degradation of habitat though sightings of leopard frogs in the canyon were few before the fire and the population may never have been high (personal communication, Don Swann, biologist, Saguaro National Park, 2006).

Chimenea Creek is one of the major drainages least affected by recent wildfires in the Rincon Mountains although 43 percent of its watershed was treated with prescribed burns in the period 1994-2004 (fig. 1, table 3). Leopard frog monitoring records from 1996 through summer 2005 indicate that it has one of the densest populations of frogs in the Rincon Mountains. Within a 500-m reach of channel containing 24 tinajas (figs. 3 and 6), 895 observations of adult leopard frogs were made as well as of 294 juveniles and 1,735 tadpoles. Although there were fluctuations in the frequency of observations, there was no extended period of zero observations. Four tinajas were surveyed to determine sediment volumes that ranged from 0 to 20 percent of the pool volume (fig. 15, table 5). All of those tinajas supported leopard frog populations, ranging from 19 to 55 adult frogs, observed during the monitoring period.

About 30 percent of the Madrona Canyon watershed burned in the 1994 Rincon fire, most of that in the south fork sub-basin (fig. 1, table 3). Two tinajas were surveyed to determine sediment storage (fig. 15, table 5). Pool MAD2, which is downstream from the two branches of Madrona Canyon (fig. 3) and would have been most affected by the 1994 Rincon fire that burned 70 percent of the south fork watershed, contained 42 percent sediment volume. Pool MAD9 is located in the north fork of Madrona Canyon, about 9 percent of which was burned in 1999, contained 31 percent sediment volume (fig. 15, table 5). No leopard frogs were found in either branch of Madrona Canyon in a survey conducted immediately after the fire in July 1994 nor in a subsequent survey in 1998. Since then, 20 adult frogs, 26 juveniles and 33 tadpoles have been seen scattered through 6 of the 18 tinajas in Madrona Canyon. Four of the adult frog observations were in pool MAD2 in 1999, but none have been reported since. All of the observations were in tinajas located either in the south fork or in the reach below the junction of the two forks downstream from the 1994 burn area. The number of leopard frog observations is so low as to make their presence or absence inconclusive indicators of post-wildfire effects on the quality of frog habitat in Madrona Canyon. Likewise, the volume of sediment in the two tinajas that were sampled does not shed much light on post-wildfire sedimentation and recovery. Although the sediment volumes in the two tinajas were the highest of any outside of Loma Verde Wash and Wildhorse Canyon, the amount of sediment might be a result of normal episodic sediment delivery and storage. 
A. Tinaja LV4

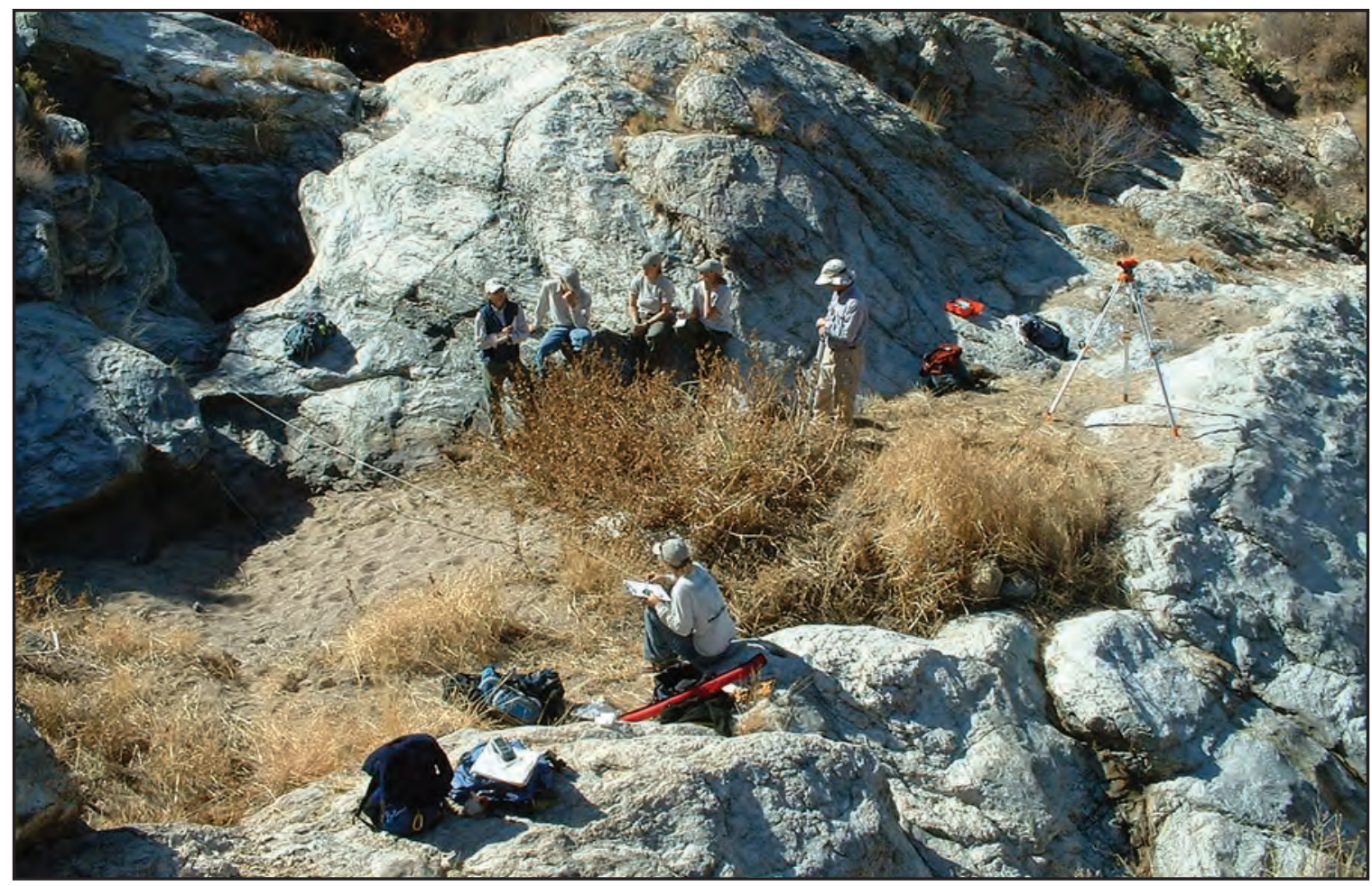

B. Tinaja LV9

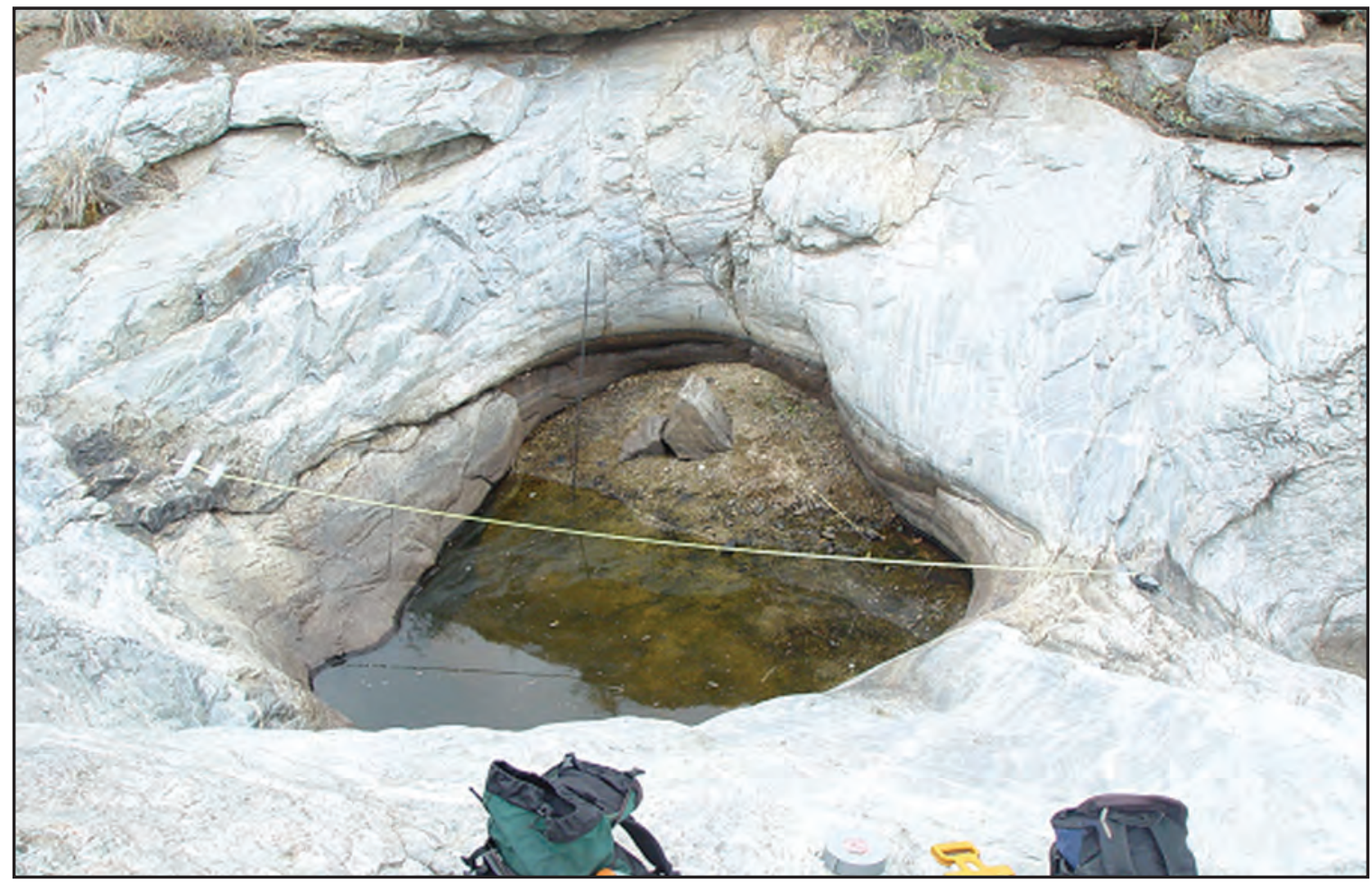

Figure 17. Tinajas in Loma Verde Wash, Saguaro National Park, Rincon Mountain District, Arizona. A, Tinaja LV4. $B$, Tinaja LV9. (Photographs from National Park Service.) 
The Rincon fire of 1994 burned about 50 percent of the upper Rincon Creek watershed. The most extensively burned sub-basins were the north fork, which was 93 percent burned and the upper central fork, which was 73 percent burned (fig. 1, table 3). Of the 26 tinajas in the upper Rincon Creek basin that have historic leopard frog populations, 24 are within or immediately downstream from those two extensively burned watersheds. Little other data are available that would aid in developing a sedimentation history of the basin. In a field survey of a $3.8 \mathrm{~km}$ reach of Rincon Creek from the park boundary at the lower central fork of Rincon Creek to the uppermost tinaja on the north fork (fig. 3), most tinajas mainly were free of sediment. No sediment was reported in pool RINC5 (fig. 15, table 5) when it was surveyed April 12, 2006. As of August 2006, records of leopard frog monitoring surveys in the upper Rincon Creek watershed had not been compiled.

\section{Sedimentation Rates}

The only sedimentation data available for the Rincon Mountains are the sediment accumulation rate for the tinajas of Loma Verde Wash and rough estimates of accumulation rate in pool JC5 in Joaquin Canyon (figs. 3 and 11). The amount of sediment in storage within the Loma Verde Wash tinajas has not been significantly reduced since they were filled with sand and gravel two years after the Box Canyon fire. Tinajas serve as natural bedload traps of varying efficiency (Leopold, 1992). Those tinajas that are wider and deeper than the incoming channel can be expected to trap most of the bedload entering the reach until the pool is filled to capacity.

The tinajas of Loma Verde Wash filled from upstream to downstream over a two year period suggesting that bedload transport was trapped during intermittent flows and the front of the sediment slug did not progress until upstream pools were filled. In Joaquin Canyon as well, the slug of sediment did not move past pool JC5 until the tinaja was filled sometime between June and October 2005.

Seven tinajas in Loma Verde Wash, surveyed in 2005-06, had a pool volume of $81.65 \mathrm{~m}^{3}$, of which $73.21 \mathrm{~m}^{3}$ were filled with sediment; however, pools LV1 and LVAV2 had been partially excavated by volunteer crews in May 2005 and had remained so at the time of the pool surveys. Both pools were about 100 percent filled with sediment at the time they were excavated, and when the amount removed is restored to the total sediment volume that would otherwise have been in the pools at the time of the surveys, the volume of sand and gravel is $86.21 \mathrm{~m}^{3}$ or 106 percent of the total pool volume. The mean pool volume based on the measured volumes in Loma Verde Wash is $11.6 \mathrm{~m}^{3}$. That value applied to the 38 tinajas in the channel gives a total pool volume of $440.8 \mathrm{~m}^{3}$, which then would have been the volume of sediment stored in the tinajas two years after the Box Canyon fire when they were buried. About a third of the Loma Verde Wash watershed had been burned in the 1994 Mothers Day fire (fig. 1, table 3), and it cannot be assumed that the tinajas were completely empty of sediment when they were buried after the Box Canyon fire. The amount of sediment that was stored in the tinajas before the Box Canyon fire; however, was not so great as to be noticed by park staff during leopard frog surveys. Assuming that at the time of the Box Canyon fire 15 percent of the volume of the tinajas was occupied by sediment, which is about the average sediment volume in the tinajas of the lightly burned Chimenea Creek watershed (table 5), approximately $375 \mathrm{~m}^{3}$ of sediment went into storage in the two years after the fire when all of the pools were filled to capacity (fig. 4). That would represent a minimum annual sediment yield for the entire 1,070 ha watershed of $0.175 \mathrm{~m}^{3} \mathrm{ha}^{-1} \mathrm{yr}^{-1}$, or, given a bulk density for dry sand and gravel of $1,650 \mathrm{~kg} \mathrm{~m}^{-3}$, about $289 \mathrm{~kg} \mathrm{ha}^{-1}$. Because the channels of the Rincon Mountains generally are supply limited and the amount of sandy gravel that is stored in the channels is low under normal conditions, almost all of the sediment that was deposited in the tinajas probably came from the 68 percent of the Loma Verde Wash watershed that was burned in 1999 (table 3). That increases the post-wildfire sediment yield to a minimum of $0.258 \mathrm{~m}^{3}$ $\mathrm{ha}^{-1} \mathrm{yr}^{-1}$, or about $425 \mathrm{~kg} \mathrm{ha}^{-1} \mathrm{yr}^{-1}$

In Joaquin Canyon, the timing of the filling of pool JC5 is better constrained than that for the Loma Verde Wash tinajas though the volume of sediment deposited is only roughly estimated. Between June 2004 and June 2005, a slug of sand and gravel had been deposited in the pool, but there was no indication of excess sedimentation downstream from the pool and by October 2005, JC5 was full and the sediment front had traveled about $400 \mathrm{~m}$ downstream. The amount of sediment in storage from JCP5 to the front of the sediment slug was probably about $500-1,000 \mathrm{~m}^{3}$ by October 2005 . Assuming a one-year period to fill the pool JC5 and assuming a nearly 100 percent efficient bedload trap, that would be sediment yield of about 0.593 to $1.19 \mathrm{~m}^{3} \mathrm{ha}^{-1} \mathrm{yr}^{-1}$ from the 843-ha burn area or about $980-1,960 \mathrm{~kg} \mathrm{ha}^{-1} \mathrm{yr}^{-1}$.

The sedimentation rates based on filling of tinajas in Loma Verde Wash and Joaquin Canyon are low compared to most of the post-wildfire sediment loss rates in various western watersheds summarized in Robichaud and others (2000). Published annual post-wildfire sediment loss rates for Arizona watersheds have ranged from $72,000 \mathrm{~kg} \mathrm{ha}^{-1}$ to $372,000 \mathrm{~kg}$ $\mathrm{ha}^{-1}$ in mixed-conifer forests; from $1,000 \mathrm{~kg} \mathrm{ha}^{-1}$ to $1,600 \mathrm{~kg}$ $\mathrm{ha}^{-1}$ in severely burned Ponderosa pine forests and from $3 \mathrm{~kg}$ $\mathrm{ha}^{-1}$ to $20 \mathrm{~kg} \mathrm{ha}^{-1}$ for low to moderately burned areas; and from $29,000 \mathrm{~kg} \mathrm{ha}^{-1}$ to $204,000 \mathrm{~kg} \mathrm{ha}^{-1}$ in chaparral. Also, sediment loss rates of $30 \mathrm{~kg} \mathrm{ha}^{-1}$ to $8,000 \mathrm{~kg} \mathrm{ha}^{-1}$ have been published for juniper and grasslands in Texas. Comparison of sediment data is complicated because of the different processes that are measured and reported, and the large variation in topography, vegetation cover, fire severity, short-term climatic conditions, sediment characteristics and size of sampling area. Sediment loss rates are also problematic data to apply to calculation of sediment yield from a basin. Sampling areas typically are plot-size to hillslope to small watershed. Sediment loss from hillslopes and small watersheds generally does not translate into equivalent sediment yield from a larger drainage basin 
because of deposition into storage for varying degrees of time between the source and the drainage basin outlet (Meade, 1988; Nearing and others, 2005). Because leopard frog habitat is located at the downstream end of the major tributaries in the Rincon Mountains, the basin sediment yield is a more important quantity in evaluation of the hazard posed by excess post-wildfire sedimentation than sediment loss rates. Sediment loss rates do, however, illustrate the magnitude of change in sediment transport as a result of wildfires.

Although the true sediment yield to the lower reaches of Loma Verde Wash and Joaquin Canyon as a result of the 1999 and 2003 wildfires may be an order of magnitude higher than the values estimated from sediment storage, these estimates do provide a minimum value to evaluate the hazard that postwildfire sedimentation poses to leopard frog populations.

\section{Future Fires and their Effects}

One objective of this study was to attempt to assess future fire effects on leopard frog habitat based on the physical characteristics of watersheds to determine which seemed to pose the greatest sediment hazard to the channels below them. Variation in the physical characteristics of the watersheds, such as drainage density, relief ratio, and hillslope gradient is not so striking as to present obvious sources of greater or lesser sediment delivery (fig. 6, table 1) and sediment characteristics on hillslopes and in channels are quite homogenous (table 2).

Steel Tank, Wildhorse Canyon, and Loma Verde Wash form a coterminous set of watersheds in the northwest corner of the park that have some common characteristics (table 1). They are at lower elevations than the other watersheds except for Box Canyon; are among the four highest in drainage density and all are below the average drainage area for the study area. The watershed of Steel Tank; however, has considerably shallower hillslopes than other watersheds in the Rincon Mountains and lower relief except for Box Canyon. There is little else in watershed characteristics to separate the various watersheds. The low drainage density, characteristic of most watersheds draining the west slopes of the Rincon Mountains, probably reflects strong structural control on the bedrock channels that have incised along large-scale fracture patterns.

The geology of the watersheds of the major channels is more variable though most headwater tributaries are located within the generally massive Wrong Mountain Quartzite and most tinajas that have leopard frog habitat are located in the somewhat more fractured basal part of that unit. An exception is Box Canyon, which is included entirely within the Continental Granodiorite (fig. 5). The absence of substantial data regarding the sedimentation history of Box Canyon; however, prevent making inferences about the effects of its geologic setting on sedimentation processes. Wildhorse Canyon and Loma Verde Wash are distinct in that the headwaters of the former just penetrate the granodiorite unit and four tributaries of the latter terminate in the quartz monzonite-granodiorite unit. Tinajas in the downstream reaches of both channels are located within the quartz monzonite-granodiorite unit; 50 percent of tinajas in Loma Verde Wash terminate in the quartz monzonitegranodiorite and 11 of the 113 tinajas of Wildhorse Canyon do so. There is probably some variability in sediment production from the various geologic units, particularly related to the presence of minerals such as biotite, which contribute to the production of transportable, granular material, and to the degree of deformation that produces a higher density of fracturing and jointing.

The main areas that have escaped major wildfires in the past three decades include the southern part of the Rincon Creek watershed, most of Chimenea Creek, the western part of Madrona Canyon and surprisingly, considering its sedimentation history, most of Wildhorse Canyon. Of these, the southern Rincon Creek watershed appears to have the highest fuel load with dense Ponderosa pine forest at the highest elevations and abundant understory vegetation and organic litter. Unburned areas include an 835-ha watershed immediately above 4 tinajas in lower central Rincon Creek that is primarily vegetated with oak-juniper woodland and chaparral and about 789 ha of low-lying mixed scrubgrassland, in which the tinajas are located but which is mainly non-contributing (fig. 1). The 500-ha south fork of Rincon Creek, in which two tinajas are located, is also unburned. These areas probably represent the highest threat of another major, stand-replacing brush and forest fire in the Rincon Mountains.

Neither Chimenea Creek, Madrona Canyon, nor Wildhorse Canyon appear to have nearly the fuel loads that Rincon Creek does, but as the history of Loma Verde Wash and Wildhorse Canyon shows, catastrophic sedimentation can take place in watersheds that would not be expected to have particularly high fuel loads. The Box Canyon burn area completely overlapped the area of the Mothers Day fire that burned only five years earlier and which did not prevent the increase in sedimentation that buried the Loma Verde Wash tinajas. In fact, the history of Rincon Mountain sedimentation suggests that frog habitat in any watershed may be at risk from post-wildfire sedimentation even when a small part of the watershed is involved in a severe fire as was the case in the Chiva fire that burned only 17 percent of the Wildhorse Canyon watershed (fig. 1, table 3). The detailed record of leopard frog observations in Wildhorse Canyon and Madrona Canyon and anecdotal reports in Box Canyon appear to show nearly total post-wildfire loss of habitat in all three watersheds although recovery does seem to be taking place in the first two canyons.

Persistence of high volumes of stored sediment in the lower reaches of Loma Verde Wash and Wildhorse Canyon may reflect the physical characteristics of the tinajas in those reaches rather than exceptional watershed conditions. The Wrong Mountain Quartz Monzonite-Continental Granodiorite geologic unit (fig. 5) in which half of the Loma 
Verde Wash tinajas and 10 percent of the tinajas in Wildhorse Canyon are found is more fractured and structurally complex than geologic units in the upper watersheds (Drewes, 1977). This structural complexity appears to favor the formation of tinajas that result from obstruction of flow behind bedrock dams (fig. 17A) in which deposition is facilitated by the damping of stream velocities. In the more massive quartz monzonite unit in which most stream channels and tinajas are located (fig. 5), potholes and crevices that were formed by abrasive action of sand in high-velocity flows are the predominant type of tinaja. These pools, found in smooth, fluted bedrock reaches are more likely to scour during subsequent high flows (fig. 17B).

\section{Management Considerations}

The park service is attempting to restore a more natural fire regimen to the Rincon Mountains at the same time it is attempting to preserve and enhance conditions that permit the continued existence of the leopard frog. A critical question is whether fire management tools such as prescribed burns and managed wildfires complement or conflict with wildlife management objectives.

The only watershed that has had a significant portion of its area burned but has not seen a major stand-replacing wildfire in the past three decades is Chimenea Creek. Since 1989, nearly 50 percent of the Chimenea Creek watershed has been burned (some areas have been burned more than once), of which only 11.8 percent was caused by major, severe wildfires (fig. 1, table 3). The area within the Chimenea Creek watershed that was burned in the Box Canyon fire is drained by tributaries that enter the main channel downstream from leopard frog habitat. Another 89 ha have been burned in small wildfires. Most of the burn areas in the Chimenea Creek watershed are the result of prescribed burns in the period 1994-2004. The record of leopard frog observations from 1996 through summer 2005 suggest that frog populations have not been seriously affected wildfires or prescribed burns during this period, and sediment storage in Chimenea Creek tinajas was at or below 20 percent of pool capacity in 2005 , which may be a background level for such storage. The implications of the leopard frog observations and the sediment storage volume data in Chimenea Creek are that leopard frog habitat has not been adversely affected by fire and may have been protected from such effects by management practices that reduced fuel loads in the upper watershed and possibly prevented large, severe wildfires from occurring there.

As of summer 2006, the most threatened areas of leopard frog habitat appeared to be the central and southern Rincon Creek watersheds and Wildhorse Canyon. The Rincon Creek watersheds are possibly at risk because of high fuel loads in the steep terrain above existing leopard frog habitat. Wildhorse Canyon appears at risk because of its record of heavy sedimentation in response to the burning of less than 20 percent of its watershed in 1989 and the persistence of high sediment storage volumes in the lower tinajas. Prescribed burning in fire-adapted vegetation zones and management of exotic grasses in Sonoran scrubland might decrease the risk of future severe wildfires in those areas.

The repopulation of leopard frogs in watersheds from which they had seemed to disappear following major wildfires, namely Wildhorse Canyon and Madrona Canyon, indicates that refuge areas exist within those watersheds. Leopard frogs likely survived through periods of high sedimentation well before the watersheds of the Rincon Mountains were subject to fire suppression and fire management. Identification of such refuge areas and management to protect such areas from severe wildfires might insure survival of the species in the event of future catastrophic sedimentation in the lower reaches of stream channels.

\section{Summary and Conclusions}

Post-wildfire sediments in the Rincon Mountains are delivered to the tinajas that provide habitat for lowland leopard frogs and other aquatic organisms by a variety of processes. In the first year or several years after a hot, stand-replacing wildfire, hillslopes are bare, permitting the intensification of processes, such as soil creep and dry ravel, that operate at lower rates in pre-fire conditions. The absence of tree canopy, understory vegetation, organic ground-surface litter and possible fire-related hydrophobicity of soils, increases the volume of surface runoff leading to higher stream discharges. The record of stream discharge at the Rincon Creek gage station preceding and following the 1994 Rincon fire provides the only conclusive documentation of a fire-related discharge increase in the study area. Although such hydrologic changes almost certainly occurred as a result of the Chiva, Box Canyon and Helens II fires as well. Gage records at Tanque Verde Creek and Pantano Wash downstream from those fires do not show a discharge increase that can be attributed to postfire conditions, probably because the burn areas were too small relative to the entire contributing area above the gage so that any hydrologic effects were attenuated by the time streamflows from the fire areas reached the gage station.

Increased surface runoff in combination with the exposure of the ground surface to the direct energy effects of precipitation produces an increase in surface erosion and delivery of sediment to headwater tributaries. The first rains after a wildfire flush a large amount of fine sediment, nearly a hundred percent ash, from the slopes, and this material is quickly transported to the lower reaches of the channel system. Mineral soil, primarily very poorly sorted sandy gravel, is then eroded, mainly by rainsplash and sheetwash, resulting in a diffuse wave of sediment downslope. Rills and gullies are scarce, probably because the generally coarse sediment lacks the cohesion to retain a defined narrow channel. 
The sediment transported to the tributaries following a wildfire is added to colluvium and debris flow deposits previously stored there, and the subsequent high discharges scour the channels, sending a slug of fine gravel and coarse sand downstream. The sediment slug moves episodically downstream as a series of debris flows or hyperconcentrated streamflows that occur as intense summer precipitation generates flows that remobilize the sediment. Under postfire conditions in the Helens II fire area, the sediment slug apparently moved only several hundred meters in each event. As the slug enters lower reaches, it overwhelms the transport capacity of the channel system and fills the channel bed and tinajas, burying any existing leopard frog habitat.

Watershed recovery proceeds by revegetation and perhaps by depletion of available sediment that occurs by winnowing of finer-grained sediment particles and the formation of a gravel armor on the ground surface. Although the process of armoring was observed in the Helens II burn area, its significance as a stabilizing factor in the watershed is not certain. Sediment transport from the watershed appeared to attenuate after two monsoon seasons following the fire though collection of sediment transport data would have been necessary to confirm that this had occurred to a significant degree.

The residence time of sediment in the tinajas following their burial is dependent upon the frequency and magnitude of subsequent streamflows and apparently upon the morphology of the tinajas. Most tinajas in Loma Verde Wash were still filled with sediment six years after the 1999 Box Canyon fire and some tinajas in the lower reaches of Wildhorse Canyon continued to hold high volumes of sediment 17 years after the Chiva fire of 1989. Persistent sediment storage in tinajas of other channels has not been observed, but the sedimentation history of those channels is not well known. The persistence of sediment storage in Loma Verde Wash and lower Wildhorse Canyon tinajas may reflect the type of tinaja found in those channels, especially where the channel is located within the Wrong Mountain Quartz Monzonite-Continental Granodiorite geologic unit (fig. 5). That unit is more heavily fractured than the more massive quartz monzonite of the upper watersheds and results in the formation of tinajas that are affected by depositional rather than erosional processes. The obstruction of streamflow by bedrock outcrops, sills, and boulders that ponds waters above those barriers facilitates deposition whereas the tinajas in upper reaches tend to be formed by erosive, high velocity flows in steep, smooth, fluted bedrock channels. In those tinajas, sediment can be expected to be deposited only during waning flows and to be at least partially scoured during subsequent flows.

Some scouring of tinajas in upper Loma Verde Wash, especially in polished bedrock channels, was beginning to occur by October 2005, which seemed to suggest that sediment supply in the upper watershed was becoming depleted; however, following heavy monsoon rains in July-August 2006, the pools were refilled with sediment. No leopard frogs have been observed in Loma Verde Wash since the Box Canyon fire. In Wildhorse Canyon; however, tinajas in upper reaches have generally low volumes of sediment in storage and some recovery of leopard frog populations has occurred following a period of no observations when monitoring began in 1996.

Background rates of sedimentation in tinajas and channels are far below post-wildfire rates but are not negligible. In channels beneath older burn areas or beneath unburned areas, bed material typically is very coarse gravel ranging to maximum diameters of at least $3 \mathrm{~m}$, but sand and finer-grained sediment is patchy, distributed mainly within the interstices of gravel or deposited in sparse, isolated patches of terrace and floodplain. Tinajas; however, are sediment traps and in every channel that has been surveyed, some pools have been found to contain sandy gravel or gravelly sand occupying 15-40 percent of the total pool volume. Although some of those tinajas, such as those in Madrona Canyon beneath the 1994 Rincon burn area, may still be reflecting the effects of excessive post-wildfire sedimentation, they also may be storing sediment that is delivered to the reach from normal episodic erosion and transport resulting from intense, local monsoon rains.

The rate at which tinajas in Loma Verde Wash were filled following the Box Canyon fire suggests a minimum post-wildfire sediment yield of $0.258 \mathrm{~m}^{3} \mathrm{ha}^{-1} \mathrm{yr}^{-1}$, or about $425 \mathrm{~kg} \mathrm{ha}^{-1} \mathrm{yr}^{-1}$ based on the assumptions that the tinajas contained an average volume of 15 percent stored sediment before deposition from the fire began. Although this value is much lower than most rates of sediment loss published for western watersheds, it is not an unreasonable minimum value. Sediment yields at the base of large watersheds can be expected to be considerably lower than erosion rates from hillslopes, study plots, and smaller watersheds because of sediment storage on hillslopes and channels between the erosion sites and the watershed outlet. In Joaquin Canyon, a rough estimate of sediment yield of $980-1,960 \mathrm{~kg} \mathrm{ha}^{-1} \mathrm{yr}^{-1}$ is based on the rate of filling of tinaja JC5 and the advance of a sediment slug about $400 \mathrm{~m}$ downstream from the pool between June 2004 and October 2005.

The background levels of sediment storage in tinajas is probably reflected in the amount of sediment stored in the tinajas of Chimenea Creek. Leopard frog monitoring reports appear to indicate that habitat has been lightly affected, if at all, by the fire history of the Chimenea Creek watershed. The combined pool volume of the four tinajas surveyed in 2006 (fig. 15, table 5) is occupied by about 18.5 percent sand, therefore tinajas with sediment volumes of 100 percent represent a minimum five-fold increase in sediment storage. Such an increase under post-wildfire conditions is within the bottom of the range of post-wildfire increases in sedimentation rates reported elsewhere in the western United States (Martin and Moody, 2001a; Paige and others, 2003).

Although the record of sedimentation in channels other than Loma Verde Wash, Wildhorse Canyon, and Joaquin Canyon is extremely sparse, there are some indications that these channels have undergone some degree of habitat 
destruction after severe wildfires. Anecdotal evidence that leopard frogs disappeared from Box Canyon after the Box Canyon fire and limited leopard frog observation data of Madrona Canyon since the 1994 Rincon fire suggest a history of habitat loss. In fact, leopard frog habitat appears to be at risk below any watershed that might be involved in a severe, stand-replacing wildfire. The areas that appear to be most at risk in the near future include the tinajas in the main fork and south fork of Rincon Creek below watersheds that have not been significantly burned in the past three decades. High fuel loads and steep terrain suggest that tinajas in those channels would see catastrophic rates of sedimentation although sediment storage might not be as persistent as in Loma Verde Wash and Wildhorse Canyon. Wildhorse Canyon also appears to be especially at risk based on its sedimentation history. Leopard frogs nearly disappeared from the tinajas of Wildhorse Canyon because of high rates of deposition even though the amount of watershed burned in the Chiva fire was only 17 percent. The rest of the watershed has not been significantly burned in the past three decades and even that part that was burned has been substantially revegetated.

The Chimenea Creek tinajas support the densest leopard frog habitat in the Rincon Mountains despite having nearly 50 percent of the watershed burned, mainly by prescribed burns and small wildfires (fig. 1, table 3). Such a history suggests that fire management practices have not been detrimental, at least in the long term, to leopard frog populations and perhaps have helped protect habitat by decreasing the likelihood of occurrence of large, severe wildfires.

\section{References Cited}

Arizona Fish and Game Department, 2006, Heritage Data Management System: Arizona Fish and Game Department Animal Abstract, AAABH01250, accessed June 6, 2006, at http://www.azgfd.gov/w_c/edits/documents/Ranayava.fi.pdf

Arizona State University, 2006, Arizona monthly state climate update: Tempe, Arizona State University, Office of Climatology, accessed June 16, 2006 at http://www.public. asu.edu/\%7Edellis/update.html

Baisan, C. H. and Swetnam, T. W., 1990, Fire history on a desert mountain range: Rincon Mountain Wilderness, Arizona, U.S.A.: Canadian Journal of Forest Research v. 20, p. 1559-1569.

Blott, S.J., and Pye, K., 2001, GRADISTAT, A grain size distribution and statistics package for the analysis of unconsolidated sediments: Earth Surface Processes and Landforms, v. 26, p. 1237-1248.
Bolin, S.B., and Ward, T.J., 1987, Recovery of a New Mexico drainage basin from a forest fire: Forest hydrology and watershed management, Proceedings of the Vancouver Symposium. IAHS Publication no. 167, p. 191-198.

Bowers, J.E., and McLaughlin, S.P., 1987, Flora and vegetation of the Rincon Mountains, Pima County, Arizona: Desert Plants, v. 8, p. 51-94.

Cannon, S.H., Kirkham, R.M., and Parise, M., 2001, Wildfirerelated debris-flow initiation processes, Storm King Mountain, Colorado: Geomorphology, v. 39, p. 171-188.

Cannon, S.H., Powers, P.S., and Savage, W.Z., 1998, Firerelated hyperconcentrated and debris flows on Storm King Mountain, Glenwood Springs, Colorado, USA: Environmental Geology, v. 35, p. 210-218.

DeBano, L.F., 2000, Water repellency in soils-A historical review: Journal of Hydrology, v. 231-232, p. 4-32.

Dendy, F.E., and Bolton, G.C., 1976, Sediment-yield-runoffdrainage area relationships in the United States: Journal of Soil and Water Conservation, v. 31, p. 264-266.

Dickinson, W.R., 1991, Tectonic setting of faulted Tertiary strata associated with the Catalina core complex in southern Arizona: Boulder, Colorado, Geological Society of America Special Paper 264, 106 p.

Drewes, H., 1974, Geologic map and sections of the Happy Valley Quadrangle, Cochise County, Arizona: U.S. Geological Survey Miscellaneous Investigations Series Map I-832.

Drewes, H., 1977, Geologic map and sections of the Rincon Valley Quadrangle, Pima County, Arizona: U.S. Geological Survey Miscellaneous Investigations Series, Map I-977.

Esque, T.C., and Schwalbe, C.R., 2006, Nonnative grass invasions and fire in the Sonoran desert: U.S. Geologic Fact Sheet accessed June 16, 2006, at http://www.werc.usgs. gov/invasivespecies/i-esque2.pdf

Esque, T.C., Schwalbe, C.R., DeFalco, L.A., Duncan, R.B., and Hughes, T.J., 2003, Effects of desert wildfires on desert tortoise (Gopherus Agassizii) and other small vertebrates: The Southwestern Naturalist, v. 48, p. 103-109.

Florsheim, J.L., Keller, E.A., and Best, D.W., 1991, Fluvial sediment transport in response to moderate storm flows following chaparral wildfire, Ventura County, southern California: Geological Society of America Bulletin, v. 103, p. 504-511.

Folk, R.L., 1980, Petrology of sedimentary rocks: Austin, Texas, Hemphill Publishing Company, 163 p. 
Folk, R.L., and Ward, W.C., 1957, Brazos River bar: A study in the significance of grain size parameters: Journal of Sedimentary Petrology v. 27, p. 3-26.

Kirchner, J.W., Finkel, R.C., Riebe, C.S., Granger, D.E., Clayton, J.L., King, J.G., and Megahan, W.F., 2001, Mountain erosion over $10 \mathrm{yr}, 10 \mathrm{k} . \mathrm{y}$. , and $10 \mathrm{~m} . \mathrm{y}$. time scales: Geological Society of America Bulletin, v. 29, p. 591-594.

Langbein, W.B., and Schumm, S.A., 1958, Yield of sediment in relation to mean annual precipitation: Transactions of the American Geophysical Union, v. 39, p. 1076-1084.

Leopold, L.B., 1992, Sediment size that determines channel morphology, in Billi, P., Hey, R.D., Thorne, C.R., and Tacconi, P., eds., Dynamics of gravel-bed rivers: Chichester, United Kingdom, John Wiley and Sons Ltd, p. 297-311.

MacLeod, A.H., Briggs, M., and Ostergaard, E., 2003, Identify and map water resources of the Rincon Mountain District of Saguaro National Park: Report to Water Resources Division of the National Park Service, Saguaro National Park, Desert Southwest Cooperative Ecosystems Park Studies Unit, Rincon Institute, $82 \mathrm{p}$.

Martin, D.A., and Moody, J.A., 2001a, The flux and particle size distribution of sediment collected in hillslope traps after a Colorado wildfire: Proceedings of the 7th Federal Interagency Sedimentation Conference, Reno, Nevada, p.III-40-III-46.

Martin, D.A., and Moody, J.A., 2001b, Comparison of soil infiltration rates in burned and unburned mountainous watersheds: Hydrological Processes, v. 15, p. 2893-2903.

Meade, R.H., 1988, Movement and storage of sediment in river systems, in Lerman, A., and Meybeck, M., eds., Physical and chemical weathering in geochemical cycles: Dordrech, The Netherlands, Kluwer Academic Publishers, p. 165-179.

Melton, M.A., 1965, Debris-covered hillslopes of the southern Arizona desert-Consideration of their stability and sediment contribution: Journal of Geology, v. 73, p. 715-729.

Moody, J.A., 2001, Sediment transport regimes after a wildfire in steep mountainous terrain: Proceedings of the 7th Federal Interagency Sedimentation Conference, Reno, Nevada, p. X-41-X-48.

Moody, J.A., and Martin, D.A., 2001, Post-fire, rainfall intensity-peak discharge relations for three mountainous watersheds in the western USA: Hydrological Processes, v. 15 , p. 2981-2993.

National Climate Data Center, 2006, accessed June 16, 2006, at http://www4.ncdc.noaa.gov/cgi-win/wwcgi. dll?WWDI StnSrch
Nearing, M.A., Kimoto, A., Nichols, M.H., and Ritchie, J.C., 2005, Spatial patterns of soil erosion and deposition in two small, semiarid watersheds: Journal of Geophysical Research, v. 110, F04020, doi:10.1029/2005JF000290.

Paige, G.B., Stone, J.J., Guertin, D.P., McGee, R., Blumenfeld, H., 2003, Runoff and erosion on a semi-arid grassland after a wildfire: Proceedings 2nd International Wildfire Ecology and Fire Management Congress and 5th Symposium on Fire and Forest Meteorology, November 16-20, 2003: Orlando, Florida, American Meteorological Society, accessed June 16, 2006, at http://ams.confex.com/ams/FIRE2003/ techprogram/paper_65117.htm

Parsons, D.J., and Botti, S.J., 1996, Restoration of fire in national parks in Hardy, C.C., and Arno, S.F., eds., The use of fire in forest restoration, Proceedings of Annual Meeting of the Society for Ecological Restoration, Seattle, Washington, September 14-16, 1995: USDA Forest Service General Technical Report INT-GTR-341, p. 29-31, accessed August 9, 2006, at http://www.fs.fed.us/rm/pubs/int_gtr341/ gtr341_4.html

Pettijohn, F.J., Potter, P.E., and Siever, R., 1987, Sand and sandstone: New York, Springer-Verlag, 553 p.

Pima County, Arizona, 2006, Pima County multi-species conservation plan, accessed February 17, 2006, at http://www.pima.gov/cmo/sdcp/.

Poesen, J., De Luna, E., Franca, A., Nachtergaele, J., and Govers, G., 1999, Concentrated flow erosion rates as affected by rock fragment cover and initial soil moisture content: Catena, v. 36, p. 315-329.

Poole, A., 2002, Digital Geologic Map of Saguaro National Park, Arizona: National Park Service Intermountain GIS Center, Albuquerque, New Mexico.

Robichaud, P.R., Beyers, J.L., and Neary, D.G., 2000, Evaluating the effectivness of postfire rehabilitation treatments: USDA Forest Service General Technical Report RMRS-GTR-63, USDA Rocky Mountain Research Station, 86 p., accessed August 14, 2006, at http://www.fs.fed.us/rm/ pubs/rmrs_gtr63.pdf

Saguaro National Park, 2004, Draft Saguaro National Park fire management plan environmental impact statement, 206 p., accessed August 7, 2006, at http://www.nps.gov/ applications/parks/sagu/ppdocuments/Draft\%20Saguaro\% 20Fire\%20Managment\%20Plan.pdf

Selby, M.J., 1993, Hillslope materials and processes: Oxford, Oxford University Press, $451 \mathrm{p}$.

Veenhuis, J., 2002, Effects of wildfire on the hydrology of Capulin and Rito De Los Frijoles Canyons, Bandelier National Monument, New Mexico: U.S. Geological Survey Water-Resources Investigations Report 02-4152, 39 p. 
Webb, R.H., and Betancourt, J.L., 1992, Climatic variability and flood frequency of the Santa Cruz River, Pima County, Arizona: U.S. Geological Survey Water-Supply Paper 2379.

Wells, W.G., 1987, The effects of fire on the generation of debris flows in southern California in Costa, J.E. and Wieczorek, G.F., eds., Debris flow/avalanches:Geological Society of America, Reviews Engineering Geology, v. 7, p. $105-114$.

Whipple, K.X., Hancock, G.S., and Anderson, R.S., 2000, River incision into bedrock: Mechanics and relative efficacy of plucking, abrasion, and cavitation: Geological Society of America Bulletin, v. 112, p. 490-503.

Wohl, E.E., 1998, Bedrock morphology in relation to erosional processes in Tinkler, K.J., Wohl, E.E., eds., Rivers over rock-Fluvial processes in bedrock channels: American Geophysical Union, Geophysical Monograph vol. 107, p. 133-151.

Wohl, E.E., and Pearthree, P.P., 1991, Debris flows as geomorphic agents in the Huachuca Mountains of southeastern Arizona: Geomorphology, v. 4, p. 273-292. 
Manuscript approved for publication, September 15, 2006.

Prepared by the Reports Section, U.S. Geological Survey, Tucson, Arizona.

USGS Publishing staff

Tracey L. Suzuki, Technical Editor

John Callahan, Illustrator

For more information concerning the research in this report, contact the Arizona Water Science Center Director,

U.S. Geological Survey, 520 N. Park Ave., Suite 221

Tucson, AZ 85719

http://az.water.usgs.gov 
This page left blank intentionally. 
This page left blank intentionally. 